\title{
Gastric Cancer: Identification of microRNAs Inhibiting Druggable Targets and Mediating Efficacy in Preclinical In Vivo Models
}

\author{
ULRICH H. WEIDLE ${ }^{1}$, FABIAN BIRZELE ${ }^{2}$, ULRICH BRINKMANN $^{1}$ and SIMON AUSLAENDER $^{1}$ \\ ${ }^{1}$ Large Molecule Research, Roche Pharma Research and Early Development \\ (pRED), Roche Innovation Center Munich, Penzberg, Germany; \\ ${ }^{2}$ Pharmaceutical Sciences, Roche Pharma Research and Early Development \\ (pRed), Roche Innovation Center Basel, Basel, Switzerland
}

\begin{abstract}
In addition to chemotherapy, targeted therapies have been approved for treatment of locally advanced and metastatic gastric cancer. The therapeutic benefit is significant but more durable responses and improvement of survival should be achieved. Therefore, the identification of new targets and new approaches for clinical treatment are of paramount importance. In this review, we searched the literature for down-regulated microRNAs which interfere with druggable targets and exhibit efficacy in preclinical in vivo efficacy models. As druggable targets, we selected transmembrane receptors, secreted factors and enzymes. We identified 38 microRNAs corresponding to the criteria as outlined. A total of $13 \mathrm{miRs}$ target transmembrane receptors, nine inhibit secreted proteins and 16 attenuate enzymes. These microRNAs are targets for reconstitution therapy of gastric cancer. Further target validation experiments are mandatory for all of the identified microRNAs.
\end{abstract}

Gastric cancer (GC) is the third-leading cause of cancer worldwide and is the fourth most common cancer with an annual death toll of 700000 worldwide (1). From a molecular point of view the following subtypes have been characterized: Epstein-Barr virus, microsatellite instability,

This article is freely accessible online.

Correspondence to: Ulrich Brinkmann or Ulrich H. Weidle, Roche Innovation Center Munich, Nonnenwald 2, D-82372 Penzberg, Germany. Tel: +4988566013901, e-mail: ulrich.brinkmann@ roche.com (UB),weidle49@t-online.de (UHW)

Key Words: Apoptosis, invasion, proliferation, microRNA mimetics, reconstitution therapy, transmembrane receptors, secreted factors and enzymes, target validation, xenograft models, review. genomically stable and chromosomal instability subtypes, all correlate with differential prognosis (2). Of all GCs, $90 \%$ are adenocarcinomas which arise from the glandular epithelium (2). The only curative treatment is surgery. Neo-adjuvant and adjuvant treatment are integrated with chemotherapy and radiation, nevertheless the 5-year survival rate for patients with locally advanced disease is less than $30 \%$ and in the metastatic setting, the median survival is in the range of 1 year (3-5). Preferential organs of metastasis are the liver $(48 \%)$, peritoneum $(32 \%)$, lung $(15 \%)$ and bone (12\%) (6). New treatment modalities have been introduced, such as trastuzumab in the subclass of patients with human epidermal growth factor receptor 2 (HER2)-positive tumors, and ramucirumab as second-line treatment or in combination with paclitaxel (3-5). More recently, immune-checkpoint inhibitory monoclonal antibodies (mAbs) against programmed cell death protein 1 (PD1), such as nivolumab and pembrolizumab, have been approved for patients with heavily pre-treated GC (3-6). Promising clinical studies are ongoing in claudin 18.2-positive GCs and in those with fibroblast growth factor receptor 2 (FGFR2) amplification (3-6). Nevertheless, there is an urgent need to identify new targets and treatment modalities which lead to durable responses and improved survival. Many of the recently identified targets, e.g., those involved in epigenetic modification or tumor suppressors, are undruggable or difficult to interfere with (7-9). In this review, we focus on microRNAs (miRs) which are down-regulated in GC and interfere with controllable targets (transmembrane receptors, secreted factors and enzymes) with demonstrated efficacy in GC-related preclinical in vivo models. The identified targets need to be validated for treatment of GC and concomitantly the identified miRs can be evaluated as tools for reconstitution therapy. 


\section{miRs in Cancer}

miRs are synthesized in the nucleus as pri-miRs containing a hairpin loop, processed to pre-miR hairpin structures, and are finally exported to the cytoplasm $(10,11)$. Subsequently, pre-miRs are cleaved by endoribonuclease DICER to produce a 22-nucleotide miR duplex with 5'phosphate and a two-nucleotide overhang at each end $(10,11)$. One strand of the 22-nucleotide duplex is maintained (guide strand), the other strand (passenger strand) is degraded $(12,13)$. Binding of the guide strand to the 3'-untranslated region of the corresponding mRNA leads to degradation or translational repression of the target mRNA $(12,13)$. In contrast to small interfering RNAs which target a single mRNA species, a single miR species may repress up to 100 mRNAs and vice versa each mRNA can be inhibited by up to 100 different miRs. This indicates the potential of miRs to modulate several pathways and cellular networks (14). In oncology, miRs can affect the whole cascade of oncogenic events from tumor initiation, tumor progression and metastasis, as well as angiogenesis, to interactions with the immune system and the tumor microenvironment (15-17). Several miRs may act as oncogenes or tumor suppressors in a context-dependent way, depending on the cell-type in which they are expressed (18). In a proof-of-concept (POC) experiment, genetic deletion of the miR-15/16 cluster in mice recapitulated the features of chronic lymphocytic leukemia, supporting their role as tumor suppressors (19). An oncogenic role was identified for miR-221 which induced hepatocellular carcinoma in transgenic mice after liver-specific expression and subsequently many other examples have followed (20). We recently summarized the role of miRs in metastasis of breast, ovarian, prostate, non-small-cell lung carcinoma and pancreatic cancer (21-25). In this review, we focus on miRs down-regulated in GC which have controllable targets and which mediate efficacy in preclinical GC-related in vivo models after reconstitution therapy.

\section{Transmembrane Receptor Tyrosine Kinases}

miR-7 and miR-133. miR-7 (Figure 1A) was shown to be down-regulated in GC cell lines and its expression was inversely correlated with metastasis $(26,27)$. miR-7 suppressed migration of 9811-P GC cells in Matrigel-based transwell assays and tail vein injection of GC9811-P cells stably expressing $m i R-7$ gave rise to reduced numbers of metastatic nodules in the liver of nude mice (26). miR-133a (Figure 1) was shown to inhibit proliferation of GC cell lines, their colony formation, migration, invasion, epithelialmesenchymal transition (EMT), inducing apoptosis and repressing tumorigenicity of GC cell lines SGC-7901 and MGC-803 in nude mice (27). Both miRs target insulin-like growth-factor receptor 1 (IGF-1R), a transmembrane tyrosine kinase receptor which is overexpressed in many tumor types and acts as an oncogene by conferring anti-apoptotic, prosurvival and transforming properties (28). Expression of IGF$1 \mathrm{R}$ was shown to be positively correlated with poor prognosis in patients with GC (29). Clinical studies targeting IGF-1R with mAbs or small molecules are currently underway in several types of cancer (30-32). Data from The Cancer Genome Atlas (TCGA) indicated that the steady-state RNA level of $m i R-133$ was down-regulated in GC tissues, however, $m i R-7$ was up-regulated in tumor tissues (Figure 2).

$m i R-27-3 p . m i R-27-3 p$ (Figure 1A) was shown to suppress cell proliferation and induce cell-cycle arrest in BGC-823 cells by targeting receptor tyrosine kinase-like orphan receptor 1 (ROR1) (33). AGS GC cells co-transfected with a miR-27-3p inhibitor gave rise to larger tumors after subcutaneous implantation into nude mice (33). Tumorigenicity of BGC-823 cells was suppressed after transfection with a miR-27-3p mimic and subcutaneous implantation into nude mice (33). It was shown that ROR1 induces the SRC/signal transducer and activator of transcription 3 (STAT3) signaling pathway, which activates c-MYC, cyclin D1 (CCND1) and subsequently proliferation of $\mathrm{GC}$ cells (33). ROR1 promoted the $\mathrm{G}_{0} / \mathrm{G}_{1}$ to $\mathrm{G}_{1} / \mathrm{S}$ transition in $\mathrm{GC}$ cells and was up-regulated in GC tissues compared to paired adjacent tissues (33). ROR1 is an oncofetal antigen for tumor therapy and acts as a survival factor for cancer cells (34). Hematological cancers have been the focus as a target indication of ROR1 inhibitors (35). ROR1 is highly expressed in GC (36). More comprehensive ROR1related target assessment would provide a clearer picture of the validity of this target for the treatment of GC. Data from TGCA indicate that $m i R-27 a$ was up-regulated in GC tissues in comparison to corresponding normal tissues (Figure 2).

$m i R-302 b . m i R-302 b$ (Figure 1A) inhibited cell-cycle progression and Matrigel-based invasion of AGS and SGC$7901 \mathrm{GC}$ cells by targeting transmembrane tyrosine kinase erythropoietin-producing hepatocellular carcinoma receptor A2 (EPHA2) (37). Down-regulation of EPHA2 by $m i R-302 b$ suppressed EMT (37). $m i R-302 b$ negatively regulated EPHA2/WNT/ $\beta$ catenin signaling (37). Smaller tumors were observed for SGC-7901 cells transfected with $m i R-320 b$ after subcutaneous implantation into nude mice and after tail injection, and inhibition of lung metastasis was observed (37). Activation of EMT by EPHA2 in GC has been described independently (38). EPHA2 was shown to be associated with poor survival in patients with GC (39).

\section{Other Transmembrane Receptors}

$m i R-7-5$ p. $m i R-7-5$ p (Figure 1A) was shown to be downregulated in GC stem cells positive for cluster of differentiation 44 (40). Overexpression of $m i R-7-5 p$ in GC 
a

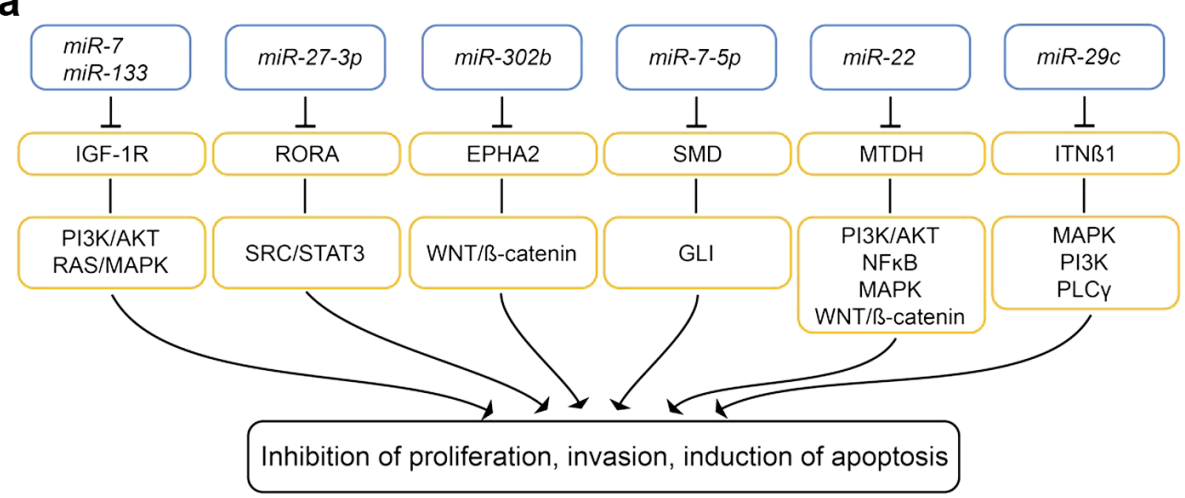

b

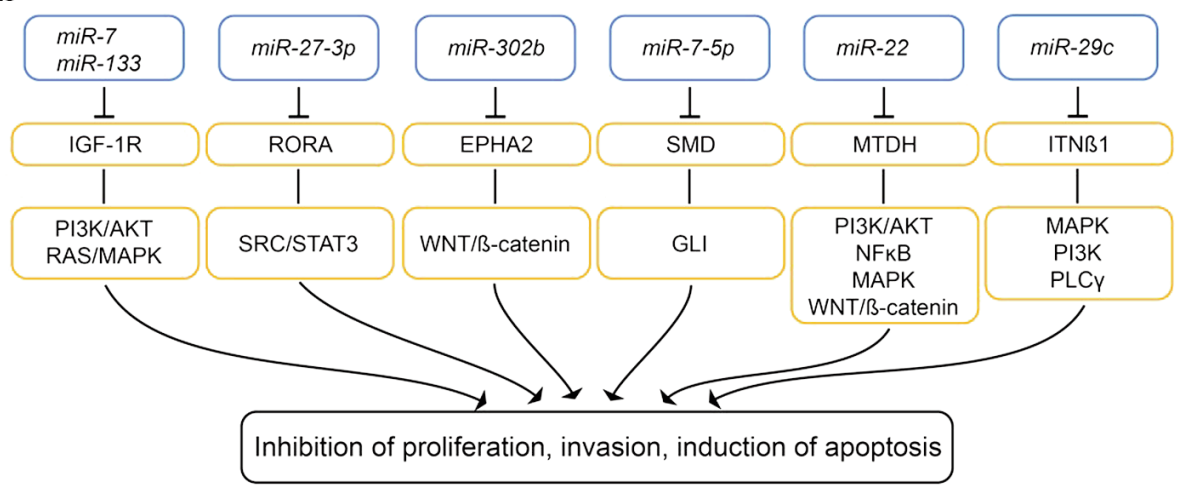

Figure 1. Down-regulated miRs targeting transmembrane receptors with activity in gastric cancer-related in vivo models. Targets and downstream effectors are shown. A: miR-7, miR-133, miR-27-3p, miR-302b, miR-7-5p, miR-22 and miR-29c; B: miR-148a, miR-218, miR-338, miR-381, miR573, miR-874 and miR-993. AKT: Serine-threonine AKT; Angio: angiogenesis; AQP3: aquaporin 3; BCL2: BCL2 apoptosis regulator; CCK-BR: cholecystokinin receptor B; COX2: cyclo-oxygenase 2; EPHA2: erythropoietin-producing hepatocellular carcinoma receptor A2; ERK1/2: extracellular signal-regulated kinase; FGF18: fibroblast growth factor 18; GLI: zinc finger protein GLI; IGFR-1R: insulin growth factor receptor 1; ITGß1: integrin $\beta 1$; JAK2: Janus kinase 2; MAPK: mitogen-activated protein kinase; MEK: MAPK kinase; MMP2,9: matrix metalloproteinase 2,9; MT1-MMP: membrane-type matrix metalloproteinase-1; MTDH: metadherin; NFkB: nuclear factor kB; PI3K: phosphatidylinositol-4,5bisphosphate 3-kinase; PLC $\gamma$ : phospholipase C $\gamma ;$ RAF: rapidly accelerated fibrosarcoma; RAS: rat sarcoma; ROBO1: roundabout1; ROR1: tyrosine kinase-like orphan receptor 1; SLC34A2: solute carrier family 34, member 2; SMD: smoothened; STAT3: signal transducer and activator of transcription 3; TGF $\beta$ : transforming growth factor $\beta$; TMEM16A: transmembrane channel 16A; TSPAN1: tetraspanin 1; WNT: WNT signaling.

stem cells led to inhibition of colony formation and reduced invasion and tumor growth inhibition in a xenograft model in nude mice (40). Smoothened and transcription factor HES1 were identified as targets of miR-7-5p (40, 41). Smoothened has been identified as a G-protein-related transmembrane receptor which plays a role in neoplastic transformation, GC development and cancer-stroma interaction $(42,43)$.

$m i R-22 . m i R-22$ (Figure 1A) was shown to be down-regulated in GC and associated with advanced clinical progression and lymph node metastasis (44). Metadherin (MTDH) was identified as a direct target of $m i R-22$ (44). Expression of MTDH was inversely correlated with $m i R-22$ levels in GC (44). $m i R-22$ inhibited GC cell proliferation and invasion by targeting MTDH in SGC-7901 cells (44). SGC-7911 cells expressing $m i R$-22 gave rise to less lung metastatic nodules after tail vein injection in nude mice (44). MTDH was shown to be overexpressed in several types of cancer and to modulate pathways such as phosphatidylinositol-4,5-bisphosphate 3kinase $(\mathrm{PI} 3 \mathrm{~K}) / \mathrm{AKT}$, nuclear factor $\mathrm{kB}(\mathrm{NFKB})$, mitogenactivated protein kinase (MAPK) and $\mathrm{WNT} / \beta$ catenin signaling $(45,46)$. In GC, MTDH promoted the malignant phenotype and induced EMT (47). Data derived from TCGA did not confirm that $m i R-22$ was down-regulated at the RNA level in GC tissues (Figure 2).

$m i R-29 c$. Expression of integrin $\beta 1$ (ITG $\beta 1$ ) was found to be reduced in GC in comparison to corresponding normal tissues (48). Ectopic expression of $m i R-29 c$ (Figure 1A) in 


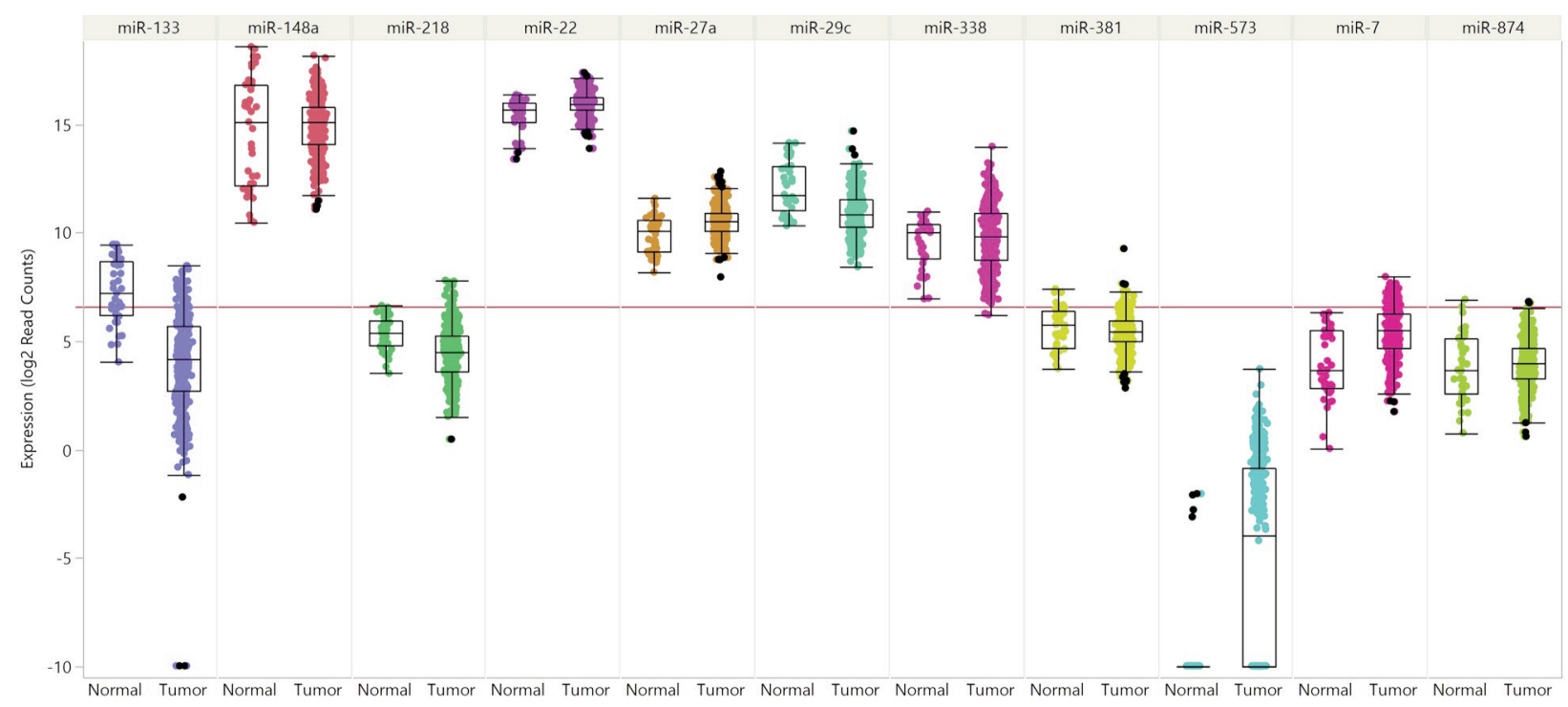

Figure 2. Expression of selected miRs in gastric adenocarcinoma compared to normal tissues. Data are shown for miR-133, miR-148a, miR-218, miR-22, miR-27a, miR-29c, miR-338, miR-381, miR-573, miR-7 and miR-874. Data from 436 tumor samples and 41 normal stomach samples derived from The Cancer Genome Atlas are shown. miR expression was quantified by RNA sequencing and is shown as log 2 of normalized read counts. The red lines indicate lower versus higher expression around 100 counts. Expression data are shown as box plots. The line represents the median value, the rectangles show the upper and lower 25\% quartiles, and $50 \%$ of all data points are included in the greater rectangle. All of the data points, except for the outliers are located within the upper and lower whiskers.

GC cell lines inhibited proliferation, adhesion, invasion, migration and suppressed xenograft tumor growth in nude mice (48). $m i R-29 c$ expression stepwise decreased during hyperplasia-dysplasia transition in transgenic mice models of GC (48). Loss of ITG $\beta 1$ expression is an early step in GC carcinogenesis (48). ITG $\beta 1$ was shown to play an important role in angiogenesis, sustained proliferative signaling, resistance to cell death, evasion of immune destruction and metastasis of several types of cancer (49-51). Data derived from TGCA have confirmed that $m i R-29 c$ was downregulated in GC tissues at the RNA level in comparison to corresponding normal tissues (Figure 2).

$m i R-148 a$. miR-148a (Figure 1B) was shown to be downregulated in GC tissues and cell lines in comparison to corresponding controls (52). miR-148a inhibits proliferation and migration in NCI-N87, SGC-7901 and MKN-45 GC cell lines (52). Ectopic expression of miR-148a attenuated tumorigenicity of GC cell lines after their subcutaneous implantation in nude mice (52). Receptor for cholecystokinin B (CCK-BR) was identified as a target for miR-148a (52). Its ligand, cholecystokinin B is a peptide hormone secreted by enteroendocrine cells which, together with gastrin, binds to CCK-AR and CCK-BR in the gastrointestinal-tract and the brain $(53,54)$. CCK-BR is overexpressed by many GCs and when activated by gastrin stimulates tumor growth by an autocrine mechanism $(53,54)$. Gastrin acting on CCK-BR induces cyclo-oxygenase 2 (COX2) and janus kinase 2 (JAK2)/STAT3/PI3K/AKT signaling (55). Data derived from TCGA did not reveal a difference in RNA steady-state levels of $m i R-148 a$ in GC tissues in comparison to corresponding normal tissues (Figure 2).

$m i R-218 . m i R-218$ (Figure 1B) was found to be decreased in $\mathrm{GC}$, and was associated with advanced clinical stage, lymph node metastasis and poor patient prognosis (56). In MKN28 GC cells transfected with $m i R-218$, no effect on proliferation or the cell cycle was noticed, however, cell migration and invasion were inhibited (56). After tail vein injection, complete inhibition of liver and lung metastases was observed in nude mice (56). Roundabout 1 (ROBO1) was identified as a direct target of $m i R-218$ (56). ROBO1 is part of a gene family containing four members with five cytoplasmic immunoglobulin domains each, three fibronectin type III repeats, a transmembrane domain and four conserved motifs in the cytoplasmic domain. The ROBO- family interacts with three types of SLIT ligands (57). The SLIT/ROBO pathway is involved in axonal repulsion, axon guidance, neuronal migration in the nervous system and formation of the vascular system (57). ROBO1 was found to be overexpressed in cancer cells and to promote tumor angiogenesis and metastasis via interaction with SLIT ligands (58). In GC, contradictory 
functions for SLIT/ROBO signaling have been reported by different groups $(59,60)$. The role of the SLIT/ROBO pathway as a target for development of anticancer drugs is under active investigation (61). Data derived from TGCA revealed that $m i R-218$ is down-regulated in GC tissues in comparison to corresponding normal tissues (Figure 2).

$m i R$-338. $m i R-338$ (Figure $1 \mathrm{~B}$ ) was shown to be downregulated in GC tissues and cell lines (62). $m i R$-338 directly targeted neuropilin1 (NRP1), inhibited proliferation, migration, invasion and promoted apoptosis in AGS and MKN-45 GC cells (62). miR-338 inhibited EMT and phosphorylation of extracellular regulated kinase $1 / 2$ (ERK1/2), p38 MAPK and AKT via NRP1 (62). miR-338 ectopically expressed in AGS and MKN-45 GC cells reduced tumor growth which was restored by expression of NRP1 (62). NRP1 is a multifactor non-tyrosine kinase receptor which is involved in development of the nervous system and which acts as a receptor for VEGFA in both endothelial and tumor cells and affects tumor growth as a co-receptor for VEGF receptor and transforming growth factor $\beta$ receptor I (TGF $\beta$ RI) and TGF $\beta$ RII, platelet-derived growth factor, receptor tyrosine kinase c-MET and semaphorin 3A. NRP1 promotes proliferation, migration, invasion and survival of tumors cells, as well as angiogenesis $(63,64)$. A mAb directed against NRP1 is presently in clinical studies in patients with solid tumors (65). Data derived from TCGA revealed that $m i R-338$ was slightly down-regulated at the RNA level in GC tissues in comparison to corresponding normal tissues (Figure 2).

$m i R-381 . m i R-381$ (Figure 1B) was found to decreased in GC tissues and was associated with adverse clinicopathological features and poor prognosis (66). $m i R$ 381 inhibited proliferation, invasion and migration of AGS and BGC-823 GC cells, down-regulates the EMT phenotype and suppresses transforming growth factor $\beta$ (TGF $\beta$ ) signaling (66). Transmembrane channel 16A (TMEM 16A) has been identified as a target of $m i R-381$ (66). In vivo, $m i R$ 381 inhibited tumor growth of AGS and BGC-823 GC cells after subcutaneous implantation into nude mice and lung metastasis after tail vein injection (66). TMEM 16A is a voltage-gated calcium-activated anion channel which acts as a chloride channel (67). TMEM 16A mediates cell invasion by induction of TGF $\beta$ secretion, EMT and MAPK signaling in GC and several types of cancer (68-70). TMEM 16A is also involved in cell proliferation, transepithelial iron transport, neuronal excitability and many other physiological functions. The structure of TMEM 16A has not yet been resolved (71). Data derived from TCGA revealed that $m i R$ 381 was slightly down-regulated at the RNA level in GC tissues in comparison to corresponding normal tissues (Figure 2). $m i R-573$. Knock-down of tetraspanin 1 (TSPAN1) led to inhibition of proliferation and invasion of BGC-23 and HGC-27 GC cells (72). BGC-823 and HGC-27 cells expressing miR-573 (Figure 1B) suppressed tumorigenicity after subcutaneous implantation into nude mice (72). TSPAN1 is up-regulated in GC and TSPANs plays a central role in this type of tumor $(73,74)$. TSPAN1 promoted EMT and metastasis of cholangiocarcinoma via PI3K/AKT signaling (75). TSPANs are associated with proliferative status and metastasis of cancer cells $(76,77)$. Targeting of TSPANs is subject of several drug discovery efforts (78). Data derived from TCGA indicated very low expression of $m i R-573$ and equal RNA steady-state levels in GC tissues and corresponding normal tissues (Figure 2).

$m i R-874 . m i R-874$ (Figure 1B) was shown to target aquaporin 3 (AQP3) and its ectopic expression in GC cell lines suppressed growth, migration, invasion and promotes apoptosis in vitro (79). In vivo, miR-874 suppressed tumorigenicity of GC cells after subcutaneous implantation into nude mice (79). Concomitantly, miR-874 downregulated BCL2 apoptosis regulator (BCL2), membrane-type matrix metalloproteinase 1 (MT1-MMP) and matrix metalloproteinases 2 and 9 (MMP2 and -9) (79). AQPs consist of monomers possessing six transmembrane domains and form homotetramers mediating water transport, membrane permeability and energy homeostasis (79). AQP3 is found at the basolateral plasma membrane of human gastric mucosal tissues, mediates cancer cell proliferation, migration, angiogenesis, metastasis and promotes stem-like properties of human GC cells by activating WNT/ $\beta$ catenin signaling (80-82). AQP3 expression was associated with poor prognosis of GC (83). The downstream effects of AQP3 need to be resolved in more detail to identify markers for drug discovery projects. Data derived from TCGA indicate that mR-874 was slightly more highly expressed in GC tissues in comparison to corresponding normal tissues (Figure 2).

$m i R-993$. miR-993 (Figure 1B) was found to be downregulated in GC and low expression was correlated with poor clinical outcome (84). miR-993 suppressed proliferation, invasion and migration of SGC-7901, MNK-45 and AGS GC cell lines in vitro (84). In an orthotopic xenograft model, miR-993 inhibited growth of miR-993-transfected SGC-7901 cells, attenuated phosphorylation of ERK1/2 and the rapidly accelerated fibrosarcoma (RAF)/MAPK kinase (MEK)/ERK pathway (84). Solute carrier family 34 member 2 (SLC34A2) was identified as a direct target of $m i R-993$ (84). SLC34A2 is a transmembrane receptor and transports inorganic phosphate into epithelial cells via sodium ion cotransport (85). The oncogenic role of SLC34A2 remains to be resolved in more detail. 


\section{Secreted Factors}

miR-24. miR-24 (Figure 3A) was shown to be downregulated in GC tissues compared to non-matched tumor tissues (86). miR-24 expression in SGC-7901 cells inhibited proliferation, and led to cell-cycle arrest in $\mathrm{G}_{0} / \mathrm{G}_{1}$ phase and apoptosis (86). Regenerating island-derived protein $\left(\mathrm{REG}_{4}\right)$ was identified as a direct target of $m i R-24$ (86). $m i R-24$ overexpression inhibited tumorigenicity of SGC-7901 cells after subcutaneous implantation into nude mice (86). $\mathrm{REG}_{4}$ is a small secretory protein expressed in gastrointestinal organs and up-regulated in gastrointestinal tumors $(87,88)$. REGs belong to the calcium-dependent lectin (C-type) superfamily and $\mathrm{REG}_{4}$ contains a single carbohydrate recognition domain (86). $\mathrm{REG}_{4}$ induces proliferation, regeneration, carcinogenesis, survival, activates epidermal growth factor receptor (EGFR)/AKT and is associated with poor prognosis in $\mathrm{GC}(87,88)$. Identification of receptors and components of downstream signaling should be resolved for $\mathrm{REG}_{4}$ target validation in GC.

$m i R-26 a / b$. $m i R-26 a / b$ (Figure 3A) was shown to be downregulated in serum and tissues of patients with GC (89). miR$26 \mathrm{a} / \mathrm{b}$ inhibited proliferation and migration of MGC-803 and SGC-7901 GC cells (89). Hepatocyte growth factor (HGF) was identified as a target of $m i R-26 a / b(88)$. Overexpression of HGF in GC cells stimulated increase in VEGF expression (89). $m i R-26 a / b$ ectopically expressed in MGC-803 GC cells inhibited tumorigenicity and vessel growth in nude mice after subcutaneous implantation, whereas HGF strongly boosted vessel and tumor growth (89). HGF-c-MET interaction plays a pivotal role in the growth, survival and invasiveness of GC and aberrant activation of this pathway is correlated with poor clinical outcome (90). Several mAbs directed against HGF and c-MET, as well as selective c-MET tyrosine kinase smallmolecule inhibitors, are presently under clinical investigation in patients with GC (90-93).

$m i R-107$. Transfection of SGC-7901 cells with miR-107 (Figure 3A) reduced cell proliferation, wound healing and migration in transwell assays, and inhibited tumor growth of these cells in nude mice after subcutaneous implantation (94). Brain-derived neurotrophic factor was identified as a target of $m i R-107$ (94), interacts with tropomyosin receptor tyrosine kinase B and mediates cancer cell growth, proliferation, survival and EMT by stimulating PI3K, RAS/RAF/MAPK and phospholipase $\mathrm{C}$ signaling, and transactivation of EGFR (95). Several compounds targeting TRKB are under clinical investigation in several types of cancer (95).

$m i R-126$. $m i R-126$ (Figure 3A) inhibited proliferation of SGC-7901 GC cells and ectopic expression of $m i R-126$ in SGC-7901 GC cells attenuated tumorigenesis in vivo (96).

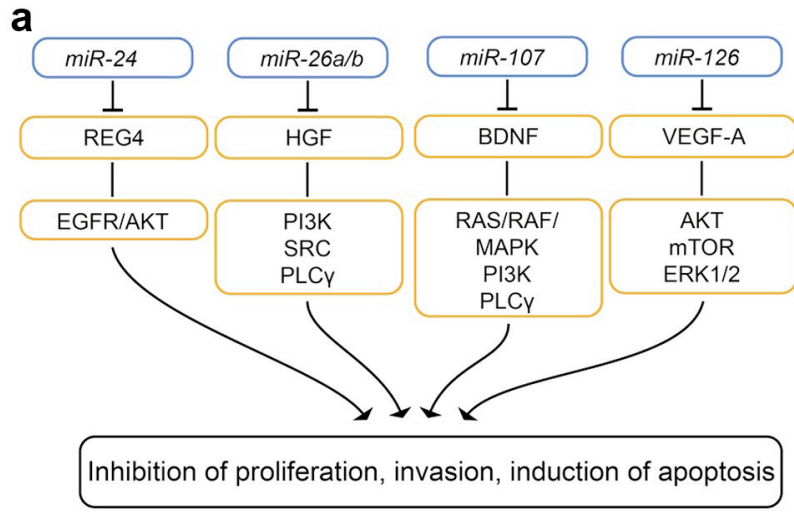

b

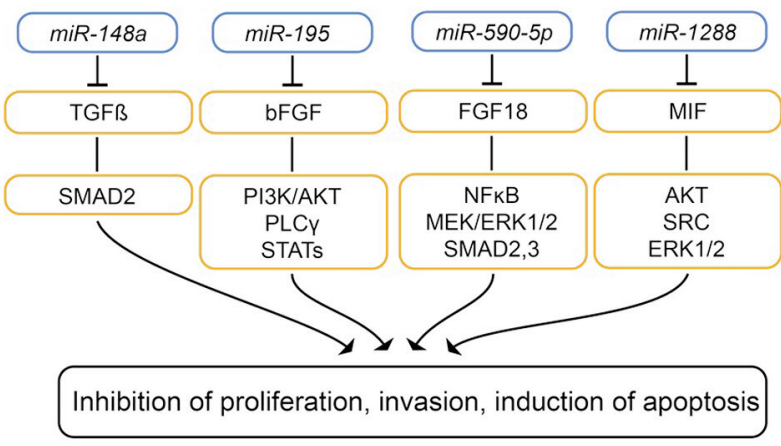

Figure 3. Down-regulated miRs targeting secreted factors with activity in gastric-cancer related in vivo models. Targets and downstream effectors are shown. A: miR-24, mIR-26a/b, miR-107 and miR-126; B: miR-148a, miR-195, miR-590-5p, miR-338 and miR-1288. AKT: v-AKT murine thyoma viral oncogene homolog ; BDNF: brain-derived neurotrophic factor; $b F G F$ : basic fibroblast growth factor; EGFR: epidermal growth factor receptor; ERK 1/2: extracellular signalregulated kinase; MAPK: mitogen-activated protein kinase; MIF: macrophage inhibitory factor; $m$ TOR: mechanistic target of rapamycin; NFkB: nuclear factor $\kappa B$; NRP1: neuropilin; $p 38$ MAPK: p38 mitogenactivated protein kinase; PI3K: phospho-inosite-3-kinase; PLC $\gamma$ : phospholipase $C \gamma$; RAS: rat sarcoma; REG4: regenerating islet-derived protein 4; SMAD2,3: small mothers against decapentaplegic homolog 2/3 ; SRC: tyrosine kinase SRC; STAT: signal transducer and activator of transcription; TGF $\beta$ : transforming growth factor $\beta$; VEGF-A: vascular endothelial growth factor $A$.

$m i R-126$ was inversely correlated with VEGF-A protein and microvessel density in GC tissue (96). VEGF-A was identified as a direct target of miR-126 (96). In SGC-7901, MKN-28 and MKN-45 GC cells, miR-126 also was shown to inhibit VEGF-A downstream targets such as AKT, mechanistic target of rapamycin (mTOR) and ERK1/2 (96). VEGF-A affects division, proliferation and migration of endothelial cells $(97,98)$. Ramucirumab, which inhibits binding of VEGF-A, -C and -D to VEGF receptor 2, is approved for treatment of advanced and metastatic GC (99). 
miR-148a. miR-148a (Figure 3B) reduced proliferation, invasion and migration of AGS, YCL3 and SCA GC cells (100). TGF $\beta 2$ and small mothers against decapapentaplegic homolog 2 (SMAD2) were identified as direct targets of miR-148a (99). $\quad N$-Methyl- $N$-9-nitro- $N$-nitrosoguanidine induced GC in rats and increased expression of TGF $\beta 2$ and SMAD2 in rat gastric tissues (100). Tumor growth of BGC$823 \mathrm{GC}$ cells ectopically expressing $m i R-148 a$ was reduced after subcutaneous implantation into nude mice (100). SMAD2 is a downstream effector of TGF $\beta 2$, therefore $m i R$ 148 increased inhibition of TGF $\beta 2$ signaling $(101,102)$. TGF $\beta 1$ and -2 play dual roles in gastrointestinal tumor development and progression and can act both as a tumor promoter and TS depending on the stage of carcinogenesis (103). Elevated levels of TGF $\beta 1 / 2$ were correlated with lymph node metastasis, poor prognosis and worse survival in patients with GC (104).

miR-195 and miR-590-5p. miR-195 (Figure 3B) inhibited migration and invasion by SNU-1 and KATO3 GC cell lines by targeting basic fibroblast growth factor (bFGF), also known as fibroblast growth factor 2 (105). Ectopically expressed $m i R-195$ inhibited tumorigenesis in a xenograft mouse model, which was restored by re-expression of bFGF (105). An inverse correlation of expression has been noted between $m i R-195-5 p$ and bFGF in human GC tissues (105). bFGF binds to FGF receptors $1,-2$ and -4 , acts as a mitogen for tumor and stromal cells, stimulates angiogenesis and activates rat sarcoma (RAS)/MAPK, PI3K/AKT, phospholipase $\mathrm{C} \gamma$ and STATs $(106,107)$. bFGF has been identified as a prognostic factor for patients with GC and several antagonists (mAbs and small molecules) are presently under clinical investigation in several types of cancer (106-108).

$m i R-590-5 \mathrm{p}$ inhibited proliferation of AGS and MKN28 GC cell lines (109). Xenograft formation was inhibited in miR-590$5 \mathrm{p}$ transfectants of these cell lines (109). FGF18 was identified as the target of $m i R-590-5 \mathrm{p}$ (109). Autocrine secretion of FGF18 promoted tumor growth of GC cell lines (109). FGF18 is a glycosylated protein which interacts with FGFR3 and FGFR4 and is abundant in GC (109). FGF18 is up-regulated in GC and is correlated with poor prognosis (109). FGF18 activates angiogenesis, NFKB, MEK-ERK signaling and SMAD2 $/ 3$, key effectors of TGF $\beta$ signaling, resulting in cancer cell proliferation and migration (109-111). Several therapeutic approaches for inhibition of FGF signaling including receptor tyrosine kinase inhibitors, receptor neutralizing $\mathrm{mAbs}$ and FGF-ligand traps have been pre-clinically validated and are under clinical investigation (112-114).

$m i R-1288 . m i R-1288$ (Figure 3B) was found to be increased in $\mathrm{G}_{0} / \mathrm{G}_{1}$ phase cells in $\mathrm{GC}$ cells and to reduce VEGF secretion (115). Conditioned media from miR-1288overexpressing GC cells reduce the capacity and to promote endothelial cell migration and tube formation in comparison to the media of control cells (115). Macrophage inhibitory factor (MIF) was identified as a target of $m i R-1288$ (115). In nude mice, coexpression of MIF with $m i R-1288$ increased tumor growth and microvascular density (115). MIF interacts with cluster of differentiation 74 (CD74) as a receptor, forms a signaling complex with CD44 and SRC and activates ERK1/2, MAPK and WNT signaling, inhibits apoptosis and reduces expression of E-cadherin (116). Furthermore, MIF induces an antitumor immune response by increasing secretion of inflammatory cytokines such as tumor necrosis factor $\alpha$, interferon- $\gamma$, interleukin- $1 \beta$ and -12 (116). MIF has at least two distinct catalytic activities as a keto-enol tautomerase and as a thiol-protein oxidoreductase, which are both druggable. The contribution of these activities to functions as described above needs still to be resolved (116). MIF is a poor prognosis factor in GC and several MIFinhibitory agents are under preclinical evaluation as anticancer agents, but for GC, more target validation experiments are required (117).

\section{miRs Targeting Enzymes}

\section{Ser-Thr Kinases}

miR-137. miR-137 (Figure 4A) was shown to be downregulated in GC cells and clinical samples (118). miR-137 inhibited proliferation, migration and induces apoptosis of GC cell lines HGC-27 and SGC-7901 (118). miR-137 attenuated tumor growth of HGC-27 and SGC-7901 cells ectopically expressing $m i R-137$ after subcutaneous implantation into nude mice and lung metastases after tail vein injection (118). v-AKT murine thymoma viral oncogene homolog 2 (AKT2) was identified as a direct target of $m i R$ 137 (118). miR-137 also down-regulated AKT2 effectors glycogen-synthase $3 \beta$ and BCL2-antagonist-of-cell-death (BAD) (118). AKT2 is activated by PI3K or phosphoinositedependent kinases, as well as growth factors, inflammation and DNA damage, and is a mediator of survival, proliferation, migration and angiogenesis of tumor cells (119). Several small-molecule AKT inhibitors are undergoing clinical studies in cancer-related indications $(119,120)$.

$m i R-199 b / a-3 p$. Expression of $m i R-199 b / a-3 p$ (Figure 4A) was shown to be reduced in GC compared to corresponding normal tissues and inhibited proliferation of MGC-803 and SGC-7901 GC cells (121). p21 activated kinase 4 (PAK4) was identified as a target of $m i R-199 \mathrm{~b} / \mathrm{a}-3 p(121)$. $m i R$ 199b/a-3p mimics transfected into MGC-803 cells inhibited tumor growth and reduced the PAK4 level after subcutaneous transplantation into nude mice (121). miR199b/a-3p suppressed PAK4/MEK/ERK signaling in MGC- 


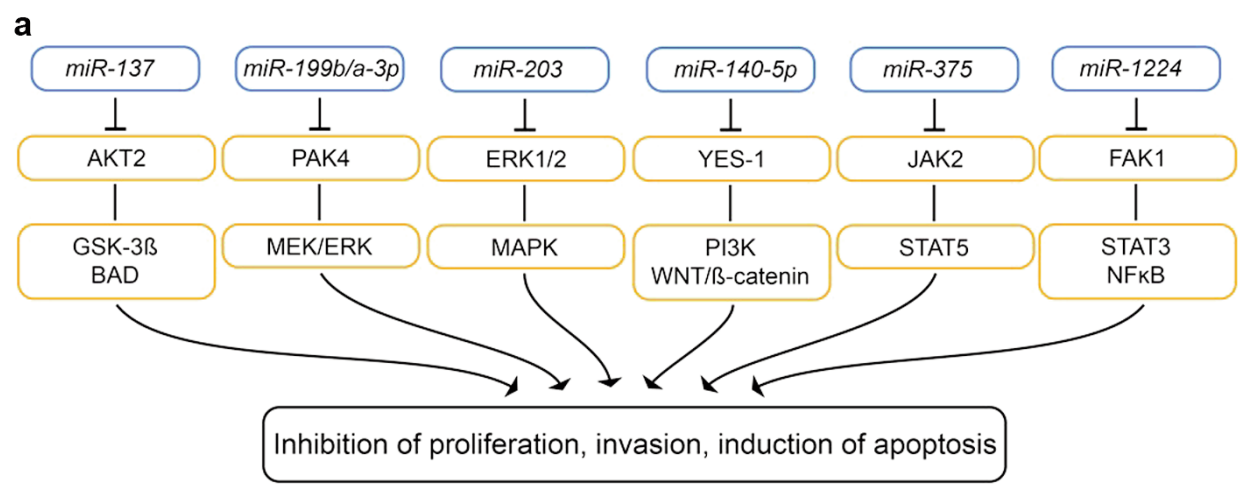

b

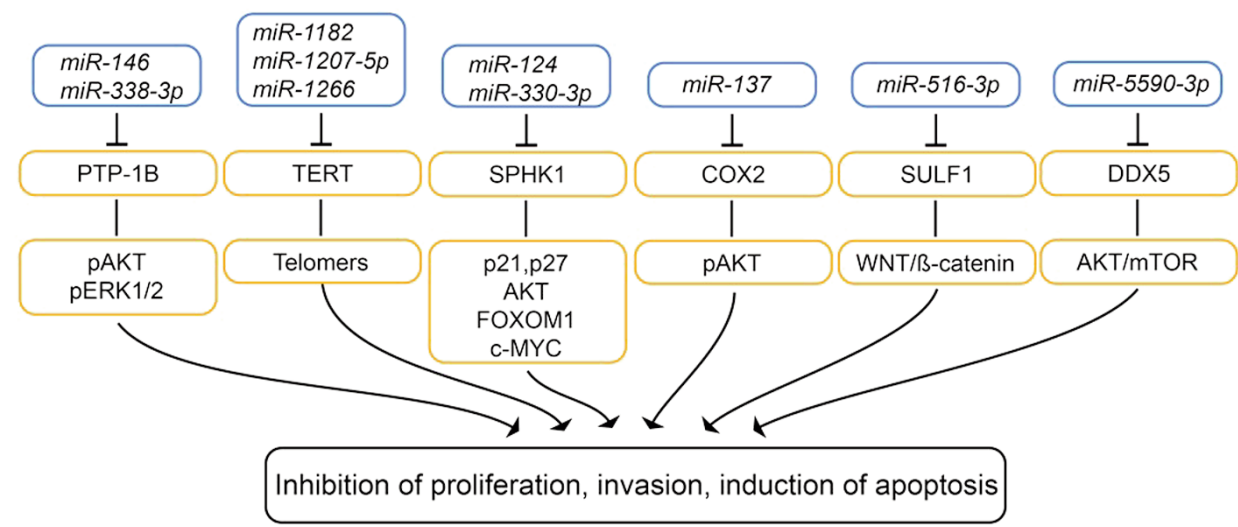

Figure 4. Down-regulated miRs targeting enzymes with activity in gastric cancer-related in vivo models. Targets and downstream effectors are shown. A: miR-137, miR-199b/a-3p, miR-203, miR-140-5p, miR-375, miR-1224; B: miR-146, miR-338-3p, miR-1182, miR-1207-5p, miR-1266, miR124, miR-330-3p, miR-137, miR-516-3p and miR-5590-3p. AKT2: v-AKT murine thyoma viral oncogene homolog 2 (AKT2); BAD: BCL2 antagonist of cell death; c-MYC: transcription factor c-MYC; COX2: cyclo-oxygenase 2; DDX5: dead box protein 5; ERK1/2: extracellular signal regulated kinase 1,2; FAK1: focal adhesion kinase 1; FOXOM1: forkhead box protein M1; GSK3 $\beta$ : glycogen synthase 3 $\beta$; JAK2: janus kinase 2; MAPK: mitogen-activated protein kinase; MEK: mitogen-activated protein kinase kinase; mTOR: mechanistic target of rapamycin; NFKB: nuclear factor kB; p21: cyclin-dependent kinase inhibitor; PAK4: p21-activated protein kinase 4; pAKT: phospho-serine-threonine kinase AKT; pERK1/2: phosphoextracellular signal regulated kinase 1,2; PI3K: phosphatidylinositol-4,5-bisphosphate 3-kinase; protein p27: cell-cycle regulatory protein; PTP1B: protein tyrosine phosphatase 1B; SPHK1: sphingosine kinase 1; STAT3,5: signal transducer and activator of transcription 3,5; TERT: telomere reverse transcriptase; WNT: WNT signaling; YES1: protein tyrosine kinase 1.

803 and SGC-7901 cells (121). PAK4 silencing inhibited proliferation of MGC-803 and SGC-7901 cells (121). Furthermore, it has been shown that PAK4 binds to translation elongation factor eEF1A1 to promote GC cell migration and invasion (122). PAK4 has been shown to mediate cancer cell proliferation, invasion, metastasis, EMT, drug resistance, WNT/ $\beta$-catenin signaling, to activate cAMP response element-binding protein and to play a role in actin/cytoskeletal organization (123). In patients with GC, high PAK4 expression is associated with poorer diseasespecific survival $(124,125)$.

$m i R-203$. Expression of $m i R-203$ (Figure 4A) was shown to be decreased in GC (126). Ectopic expression of $m i R-203$ in SGC-7901 cells inhibited invasion and motility, and reduced expression of phospho-ERK1/2 and SLUG (126). In nude mice, $m i R$-203 inhibited peritoneal metastasis of SGC-7901 cells (126). ERK1/2 contributes to MEK-ERK-MAPK signaling, which plays a role in proliferation and progression of many types of tumors, and several inhibitors of this pathway have reached clinical trials $(127,128)$.

\section{Non-receptor Tyrosine Kinases}

$m i R-140-5$ p. $m i R-140-5$ p (Figure 4A) was shown to be downregulated in GC tissues and down-regulation was correlated with poor patient survival (129). miR-140-5p suppressed proliferation, invasion and migration of AGS and BGC-823 GC cells in vitro (129). Proto-oncogene tyrosine kinase 1 (YES1) was identified as a target of miR-140-5p (129). Reconstitution of YES1 rescued miR-140-5p-mediates inhibition of GC cells 
(129). miR-140-5p suppressed growth of BGC-823 xenografts in nude mice (129). YES1 is member of the SRC-family of non-receptor kinases which is recruited to receptor tyrosine kinases and phosphorylates its substrates to activate signaling pathways. YES1 acts as a proto-oncogene and stimulates PI3K and $\mathrm{WNT} / \beta$-catenin signaling (130). YES1 is also involved in regulation of the cell-cycle and cytokinesis (131). Gene amplification of YES1 has been observed in cancer tissues (132). In GC, more detailed investigations uncovering the role of YES1 should be performed.

$m i R-375 . m i R-375$ (Figure 4A) was shown to be frequently down-regulated in GC and to inhibit proliferation of AGS and MGC-803 GC cells (133). Ectopic expression of $m i R-375$ in MGC-803 cells suppressed growth as xenografts in nude mice (133). JAK2 was identified as a target of $m i R-375$ (133). $m i R$ 375 down-regulation was associated with increase in JAK2 protein in GC (133). V617F mutation of JAK2 is involved in the pathogenesis and therapy of myeloproliferative disorders such as polycythemia vera, essential thrombocythemia and primary myelofibrosis $(134,135)$. JAK2 is a mediator of signaling of the type II cytokine receptor family, such as granulocyte-macrophage colony stimulating factor receptor, interleukin 6 receptor and erythropoietin receptor and smallmolecule inhibitors of JAK2 have been generated for treatment of myeloproliferative neoplasms (136). In GC, it has been shown that matrix vitamin K-dependent carboxylation/gamma-carboxyglutamic domain protein leads to tumor progression by JAK2/STAT5 signaling (137).

$m i R-1224$. $m i R-1224$ (Figure 4A) was shown to be downregulated in GC and this was correlated with lymph-node metastasis and poor prognosis (138). In MKN-7 and MKN28 GC cells, miR-1224 inhibited cell migration and EMT (138). MKN-7 cells transfected with a $m i R-1224$ agomir exhibited reduced lung metastasis after tail vein injection into nude mice (138). Focal adhesion kinase 1 (FAK1) was identified as a target of $m i R-1224$ (138). miR-1224-FAK 1 interaction suppressed migration and EMT of GC cells by inhibition of STAT3 and NFKB pathways (138). FAK1 is a non-receptor tyrosine kinase that mediates integrin signaling, proliferation and survival (139). The options for therapeutic intervention are small-molecule kinase inhibitors or inhibitors interfering with kinase-independent scaffolding functions. Several inhibitors are in clinical development for treatment of cancer (139-142). FAK1 has been shown to be involved in invasion and metastasis of GC (143) and inhibition of FAK1 was shown to induce apoptosis of GC cells (144).

$m i R-146 b$ and $m i R-338-3 p$. An inverse correlation between $m i R-146 b$ (Figure 4B) and its target protein tyrosine phosphatase 1B (PTP-1B) has been uncovered in GC tissues
(145). miR-146b inhibited growth of GC cells and induced apoptosis which can be reversed by PTP-1B (145). In xenografts of $m i R$-146-expressing GC cells, tumor growth was inhibited and expression of PTP-1B reduced (145).

$m i R-338-3 p$ (Figure 4B) has been shown to target PTP$1 \mathrm{~B}$, as well as attenuating migration and inducing apoptosis of GC cell lines MKN-45 and MGC-803 (146). In an orthotopic xenograft model in nude mice, tumor growth of MKN-45 cells transfected with $m i R-338-3 p$ was inhibited. Metastasis of these cells was blocked in a dissemination model in nude mice after injection into the peritoneal cavity (146). In GC cells, PTP-1B overexpression elevated the levels of pAKT and pERK1/2 (146). PTP-1B is a nonmembrane tyrosine phosphatase with tumor-suppressing and -promoting effects depending on the substrates involved and the cellular context (147). PTP-1B is a negative regulator of the insulin signaling pathway and is a potential target for treatment of type 2 diabetes (148). For GC, the role of PTP$1 \mathrm{~B}$ remains to be worked out in more detail.

miR-1182, $m i R-1207-5 p$ and $m i R-1266$. miR-1182 (Figure 4B) targeted telomerase reverse transcriptase (TERT) by binding to its open reading frame, whereas $m i R-1207-5 p$ and $m i R-1266$ bind to its 3'-untranslated region $(149,150)$. These miRs inhibited proliferation, induced cell-cycle arrest in SGC-7901 and U2OS GC cells; these effects were rescued by their antagomirs (149, 150). miR-1182 attenuated the proliferative and metastatic potential of SGC-7901 GC cells in nude mice (149). $m i R-1207-5 p$ and -1266 inhibited growth of transplanted SGC-7901 cells in nude mice (149). An inverse correlation between $m i R-1182$ and TERT expression has been noted in patients with GC (150). The telomerase complex consists of TERT and the RNA component. The loss of telomerase maintenance results in cell death and its inhibition led to improved outcomes in cancer-related xenograft models (151). The clinical development of small-molecule TERT inhibitors is hampered by efficacy issues $(152,153)$. Immunotherapeutic approaches such as vaccination against TERT are also being pursued (154). TERT expression in GC was found to have prognostic value because it is correlated with pathological variables and lymph node metastasis (155). Inhibition of TERT through reconstitution of miR-1182, miR-1207-5p or miR-1266 (Figure 4B) is an innovative approach for treatment of GC but more POC experiments should be performed.

\section{Other Enzymes}

miR-124 and miR330-3p. Sphingosin kinase 1 (SPHK1), the target of $m i R-124$ was found to be up-regulated in GC tissues and to be associated with shorter survival of patients (156, 157). $m i R-124$ (Figure 4B) was inversely correlated with SPHK1 expression in GC samples (156). miR-124 inhibited 
proliferation of GC cells in vitro and in vivo in nude mice (156). miR-124 induced downstream cell-cycle inhibitory proteins p21 and p27, suppressed AKT and enhanced the transcriptional activity of forkhead box O1 (156).

$m i R-330-3 p$ (Figure 4B) was shown to target SPHK1 and sphingosin1-phosphate receptor 1 (S1PR1) (157). Ectopic expression of $m i R-330-3 p$ inhibited proliferation, migration, in vitro invasion, and tumor growth of MKN1 GC cells after subcutaneous implantation into nude mice (157). In MKN1 and KATO3 cells, inhibition of SPHK1 by short-hairpin RNA suppressed c-MYC and increased expression of $\mathrm{p} 21$ and 27 (157). $m i R-330-3 p$ inhibited the ERK/AKT pathway in GC cells (156). SPHK1 and S1PR1 were shown to be activated in GC (158). In cancer cells, ceramide and sphingosine inhibited cell proliferation and induce apoptosis, while S1P has the opposite effect $(159,160)$. However, the issue is complicated since S1P can bind to five G-proteincoupled receptors with different outcomes regarding cell invasion. The physiological function of S1P may therefore be dependent on the S1PR receptor profile of the corresponding tumor cell $(159,160)$. Therefore, for GC more target validation experiments are necessary concerning the role of SPHK1 as a therapeutic target.

miR-137. miR-137 (Figure 4B) was found to be underexpressed in patients with GC and cell lines in comparison to corresponding controls (161). miR-137 reduced cell proliferation, and impaired migration and invasion in MGC-803 and HGC-27 GC cell lines (161). miR137 suppressed growth of MGC-803 xenografts (161). Cyclo-oxygenase 2 (COX2) has been identified as a direct target of $m i R-137$ (161). Ectopic expression of $m i R-137$ in GC cells suppressed expression of p-AKT (161). The COX2-prostaglandin pathway is activated in several types of cancer and is correlated with aggressiveness and metastasis (162). In GC, the COX2-prostaglandin pathway induces inflammatory cytokines such as IL11, chemokine (C$\mathrm{X}$-C) motif ligands 1, 2, 5 (CXCL1, 2, 5) which have tumorpromoting functions by different mechanisms (163). COX2 and $m i R-137$ deserve further target validation in GC.

$m i R-516-3 p$. A highly metastatic variant of scirrhous GC, cell line 44As3, was used to identify sulfatase-1 (SULF1) as a direct target of $m i R-516-3 p$ (Figure 4B), which shows reduced expression in GC tissues (164). Scirrhous GC exhibits a high frequency of metastasis to the peritoneum (165). Stable overexpression of $m i R-516-3 p$ in 44 As 3 cells reduced proliferation, migration and invasion in vitro (164). Longer overall survival and less ascites fluid were noticed in orthotopic 44A3 tumors intratumorally injected with an expression vector for miR-516-3p (164). SULF1 is an extracellular sulfatase which removes internal glucosamine6-sulfate from heparan sulfate proteoglycans, thereby modulating interactions with various signaling molecules $(165,166)$. SULF1 promotes WNT signaling by liberating WNT ligands which bind to frizzled receptors by an autocrine mechanism (167-169). Further target validation experiments for miR-516-3p and SULF1 in GC should be performed.

$m i R-5590-3 p . m i R-5590-3 p$ (Figure 4B) was found to be down-regulated in GC tissues and to target portable ATPdependent helicase DEAD box protein 5 (DDX5) (170). It suppressed GC cell proliferation in vitro and in vivo through the DDX5/AKT/mTOR pathway and inhibition of downstream CCND1 and cyclin-dependent kinase 2 expression (169). DDX5 is a member of the family of DEAD-box helicases $(170,171)$. DDX5 is involved in tumorigenesis, proliferation, metastasis and regulates several cancer-related pathways (172). DDX5 resolves Gquadruplexes and mediates $c-M Y C$ gene transcriptonal activation (173). The role of $m i R-5590-3 p$ and DDX5 in GC remains to be further elucidated and validated.

\section{Conclusion and Perspectives}

In this review, we did not discuss down-regulated miRs targeting MMPs with efficacy in preclinical in vivo models of GC because studies of MMP inhibitors in cancer-related indications have devalidated these targets. Identification of a down-regulated miR defines targets for therapeutic intervention which can be inhibited with small molecules, mAb-related moieties or immunological intervention. We identified $38 \mathrm{miRs}$ covering tractable targets such as transmembrane receptors $(n=13)$, secreted factors $(n=9)$ and enzymes $(n=16)$. All of the identified targets need more target-validation experiments to support their role as targets for treatment of GC. A critical issue is that several targets have tumor-promoting as well as tumor-suppressive functions in a context-dependent manner as described in the preceding sections. An important issue is the reconstitution of functions such as proliferation, invasion and survival in GC cell lines ectopically expressing the corresponding miRs through reconstitution of expression of the corresponding targets. Investigation of target-related pathways for identification of pharmaco-kinetic and pharmaco-dynamic markers is another crucial issue. The prevalence of expression of the identified targets should also be investigated in more detail.

Another option is therapeutic intervention by reconstitution therapy resulting in expression of the corresponding miR or synthetic double-stranded miR mimics in GC tumors. miRs can be administered intra-tumorally, systemically in appropriate formulations, or as plasmids or viral vectors $(13,174-176)$. Adeno-associated virus-based vectors have emerged as preferred vehicles for replacement 
therapy $(177,178)$. POC experiments in mouse lung cancer models have shown that reconstitution of Let-7 (179), miR$29 b$ (180) and miR-708-5p (181) inhibits tumor growth. Clinical approaches for reconstitution therapy have relied on $m i R-34 a$ and $m i R-16$. $m i R-34$ inhibits crucial oncogenic pathways such as EMT, NOTCH, WNT and TGF $\beta /$ SMAD and its reconstitution leads to inhibition of tumor growth in several xenograft models (182). However, a clinical phase I trial in patients with different tumors involving administration of lipid nanoparticles filled with $m i R-34$ mimetics had to be closed due to immune-related side-effects $(182,183)$. In another clinical study, EGFR-coated bacterial minicells expressing miR-16 mimics were injected into patients with metastatic pleural mesothelioma (184). miR-16 mediates a tumor-suppressive effect by down-regulation of BCL2 and CCND1 (185). In a phase I study with 27 patients with malignant pleural mesothelioma, one objective response and stabilization of disease in 15 patients was observed (185). Taken together, clinical POC for miR reconstitution therapy has not yet been achieved in patients with cancer.

From a preclinical point of view, many critical issues have to be resolved. These issues have to be tackled case-by-case and are not discussed in detail in this review. Among the critical issues are: The development of efficient delivery systems, pharmaco-kinetic and pharmaco-dynamic issues, cytokine-release syndrome, hematological and hepatic toxicity, removal of complexed nucleic acids by the reticuloendothelial system, entry into the target cell and endosomal escape $(12,186-192)$.

The next couple of years will tell us whether POC of miRbased reconstitution therapy in patients with cancer can be achieved in a clinical setting.

\section{Conflicts of Interest}

FB, SA and UB are employees of Roche; UHW has been an employee of Roche.

\section{Authors' Contributions}

FB, SA, UB and UHW jointly prepared the article and the corresponding Figures.

\section{References}

1 Van Cutsem E, Sagaert X, Topal B, Haustermans K and Prenen H: Gastric cancer. Lancet 388(10060): 2654-2664, 2016. PMID: 27156933. DOI: $10.1016 / \mathrm{S} 0140-6736(16) 30354-3$

2 Sohn BH, Hwang JE, Jang HJ, Lee HS, Oh SC, Shim JJ, Lee KW, Kim EH, Yim SY, Lee SH, Cheong JH, Jeong W, Cho JY, Kim J, Chae J, Lee J, Kang WK, Kim S, Noh SH, Ajani JA and Lee JS: Clinical significance of four molecular subtypes of gastric cancer identified by The Cancer Genome Atlas Project. Clin Cancer Res, 2017. PMID: 28747339. DOI: 10.1158/10780432.CCR-16-2211
3 Pellino A, Riello E, Nappo F, Brignola S, Murgioni S, Djaballah SA, Lonardi S, Zagonel V, Rugge M, Loupakis F and Fassan M: Targeted therapies in metastatic gastric cancer: Current knowledge and future perspectives. World J Gastroenterol 25(38): 5773-5788, 2019. PMID: 31636471. DOI: $10.3748 /$ wjg.v25.i38.5773

4 Orditura M, Galizia G, Sforza V, Gambardella V, Fabozzi A, Laterza MM, Andreozzi F, Ventriglia J, Savastano B, Mabilia A, Lieto E, Ciardiello F and De Vita F: Treatment of gastric cancer. World J Gastroenterol 20(7): 1635-1649, 2014. PMID: 24587643. DOI: $10.3748 /$ wjg.v20.i7.1635

5 Bonelli P, Borrelli A, Tuccillo FM, Silvestro L, Palaia R and Buonaguro FM: Precision medicine in gastric cancer. World J Gastrointest Oncol 11(10): 804-829, 2019. PMID: 31662821. DOI: $10.4251 /$ wjgo.v11.i10.804

6 Riihimäki M, Hemminki A, Sundquist K, Sundquist J and Hemminki K: Metastatic spread in patients with gastric cancer. Oncotarget 7(32): 52307-52316, 2016. PMID: 27447571. DOI: 10.18632/oncotarget. 10740

7 Tahara E: Genetic alterations in human gastrointestinal cancers. The application to molecular diagnosis. Cancer 75(6 Suppl): 1410-1417, 1995. PMID: 7889467. DOI: 10.1002/10970142(19950315)75:6+<1410::aid-cncr2820751504>3.0.co;2-o

8 Saha A, Wittmeyer J and Cairns BR: Chromatin remodelling: the industrial revolution of DNA around histones. Nat Rev Mol Cell Biol 7(6): 437-447, 2006. PMID: 16723979. DOI: 10.1038/nrm1945

9 Yaniv M: Chromatin remodeling: from transcription to cancer. Cancer Genet 207(9): 352-357, 2014. PMID: 24825771. DOI: 10.1016/j.cancergen.2014.03.006

10 Valencia-Sanchez MA, Liu J, Hannon GJ and Parker R: Control of translation and mRNA degradation by miRNAs and siRNAs. Genes Dev 20(5): 515-524, 2006. PMID: 16510870. DOI: $10.1101 / \mathrm{gad} .1399806$

11 Lin S and Gregory RI: MicroRNA biogenesis pathways in cancer. Nat Rev Cancer 15(6): 321-333, 2015. PMID: 25998712. DOI: $10.1038 / \mathrm{nrc} 3932$

$12 \mathrm{Li} \mathrm{Z}$ and Rana TM: Therapeutic targeting of microRNAs: current status and future challenges. Nat Rev Drug Discov 13(8): 622-638, 2014. PMID: 25011539. DOI: 10.1038/nrd4359

13 Rupaimoole R and Slack FJ: MicroRNA therapeutics: towards a new era for the management of cancer and other diseases. Nat Rev Drug Discov 16(3): 203-222, 2017. PMID: 28209991. DOI: $10.1038 / \mathrm{nrd} .2016 .246$

14 Di Leva G, Garofalo M and Croce CM: MicroRNAs in cancer. Annu Rev Pathol 9: 287-314, 2014. PMID: 24079833. DOI: 10.1146/annurev-pathol-012513-104715

15 Hashemi A and Gorji-Bahri G: MicroRNA: Promising roles in cancer therapy. Curr Pharm Biotechnol 21(12): 1186-1203, 2020. PMID: 32310047. DOI: 10.2174/13892010216 66200420101613

16 McManus MT: MicroRNAs and cancer. Semin Cancer Biol 13(4): 253-258, 2003. PMID: 14563119. DOI: 10.1016/s1044$579 \mathrm{x}(03) 00038-5$

17 Leone P, Buonavoglia A, Fasano R, Solimando AG, De Re V, Cicco S, Vacca A and Racanelli V: Insights into the regulation of tumor angiogenesis by Micro-RNAs. J Clin Med 8(12): 2030, 2019. PMID: 31757094. DOI: 10.3390/jcm8122030

18 Wen R, Umeano AC, Essegian DJ, Sabitaliyevich UY, Wang K and Farooqi AA: Role of microRNA-410 in molecular 
oncology: A double edged sword. J Cell Biochem 119(11): 8737-8742, 2018. PMID: 30086210. DOI: $10.1002 /$ jcb.27251

19 Pekarsky Y and Croce CM: Role of miR-15/16 in CLL. Cell Death Differ 22(1): 6-11, 2015. PMID: 24971479. DOI: $10.1038 /$ cdd 2014.87

20 Callegari E, Elamin BK, Giannone F, Milazzo M, Altavilla G, Fornari F, Giacomelli L, D’Abundo L, Ferracin M, Bassi C, Zagatti B, Corrà F, Miotto E, Lupini L, Bolondi L, Gramantieri L, Croce CM, Sabbioni S and Negrini M: Liver tumorigenicity promoted by microRNA-221 in a mouse transgenic model. Hepatology 56(3): 1025-1033, 2012. PMID: 22473819. DOI: 10.1002/hep. 25747

21 Weidle UH, Dickopf S, Hintermair C, Kollmorgen G, Birzele $\mathrm{F}$ and Brinkmann U: The role of micro RNAs in breast cancer metastasis: preclinical validation and potential therapeutic targets. Cancer Genomics Proteomics 15(1): 17-39, 2018. PMID: 29275360. DOI: 10.21873/cgp.20062

22 Weidle UH, Birzele F, Kollmorgen G and Nopora A: Potential microRNA-related targets for therapeutic intervention with ovarian cancer metastasis. Cancer Genomics Proteomics 15(1): 1-15, 2018. PMID: 29275359. DOI: 10.21873/cgp.20061

23 Weidle UH, Epp A, Birzele F and Brinkmann U: The functional role of prostate cancer metastasis-related micro-RNAs. Cancer Genomics Proteomics 16(1): 1-19, 2019. PMID: 30587496. DOI: $10.21873 / \operatorname{cgp} .20108$

24 Weidle UH, Birzele F and Nopora A: MicroRNAs as potential targets for therapeutic intervention with metastasis of non-small cell lung cancer. Cancer Genomics Proteomics 16(2): 99-119, 2019. PMID: 30850362. DOI: $10.21873 / \operatorname{cgp} .20116$

25 Weidle UH, Birzele F and Nopora A: Pancreatic ductal adenocarcinoma: MicroRNAs affecting tumor growth and metastasis in preclinical in vivo models. Cancer Genomics Proteomics 16(6): 451-464, 2019. PMID: 31659100. DOI: $10.21873 / \operatorname{cgp} .20149$

26 Zhao X, Dou W, He L, Liang S, Tie J, Liu C, Li T, Lu Y, Mo P, Shi Y, Wu K, Nie Y and Fan D: MicroRNA-7 functions as an anti-metastatic microRNA in gastric cancer by targeting insulin-like growth factor-1 receptor. Oncogene 32(11): 1363-1372, 2013. PMID: 22614005. DOI: 10.1038/onc. 2012.156

27 Gong Y, Ren J, Liu K and Tang LM: Tumor suppressor role of miR-133a in gastric cancer by repressing IGF1R. World J Gastroenterol 21(10): 2949-2958, 2015. PMID: 25780292. DOI: $10.3748 /$ wjg.v21.i10.2949

28 Hartog H, Wesseling J, Boezen HM and van der Graaf WT: The insulin-like growth factor 1 receptor in cancer: old focus, new future. Eur J Cancer 43(13): 1895-1904, 2007. PMID: 17624760. DOI: 10.1016/j.ejca.2007.05.021

29 Ge J, Chen Z, Wu S, Chen J, Li X, Li J, Yin J and Chen Z: Expression levels of insulin-like growth factor-1 and multidrug resistance-associated protein-1 indicate poor prognosis in patients with gastric cancer. Digestion 80(3): 148-158, 2009. PMID: 19713703. DOI: 10.1159/000226089

30 Osher E and Macaulay VM: Therapeutic targeting of the IGF axis. Cells 8(8): 895, 2019. PMID: 31416218. DOI: 10.3390/ cells 8080895

31 Werner H, Sarfstein R and Bruchim I: Investigational IGF1R inhibitors in early stage clinical trials for cancer therapy. Expert Opin Investig Drugs 28(12): 1101-1112, 2019. PMID: 31731883. DOI: $10.1080 / 13543784.2019 .1694660$
32 Simpson A, Petnga W, Macaulay VM, Weyer-Czernilofsky U and Bogenrieder T: Insulin-like growth factor (IGF) pathway targeting in cancer: role of the IGF axis and opportunities for future combination studies. Target Oncol 12(5): 571-597, 2017. PMID: 28815409. DOI: 10.1007/s11523-017-0514-5

33 Tao J, Zhi X, Zhang X, Fu M, Huang H, Fan Y, Guan W and Zou C: miR-27b-3p suppresses cell proliferation through targeting receptor tyrosine kinase like orphan receptor 1 in gastric cancer. J Exp Clin Cancer Res 34: 139, 2015. PMID: 26576539. DOI: 10.1186/s13046-015-0253-3

34 Hojjat-Farsangi M, Moshfegh A, Daneshmanesh AH, Khan AS, Mikaelsson E, Osterborg A and Mellstedt H: The receptor tyrosine kinase ROR 1 - an oncofetal antigen for targeted cancer therapy. Semin Cancer Biol 29: 21-31, 2014. PMID: 25068995. DOI: $10.1016 /$ j.semcancer.2014.07.005

35 Karvonen H, Niininen W, Murumägi A and Ungureanu D: Targeting ROR1 identifies new treatment strategies in hematological cancers. Biochem Soc Trans 45(2): 457-464, 2017. PMID: 28408486. DOI: 10.1042/BST20160272

36 Chang H, Jung WY, Kang Y, Lee H, Kim A and Kim BH: Expression of ROR1, pAkt, and pCREB in gastric adenocarcinoma. Ann Diagn Pathol 19(5): 330-334, 2015. PMID: 26245996. DOI: 10.1016/j.anndiagpath.2015.06.010

37 Huang J, He Y, Mcleod HL, Xie Y, Xiao D, Hu H, Chen P, Shen L, Zeng S, Yin X, Ge J, Li L, Tang L, Ma J and Chen Z: miR-302b inhibits tumorigenesis by targeting EphA2 via Wnt/ $\beta$-catenin/EMT signaling cascade in gastric cancer. BMC Cancer 17(1): 886, 2017. PMID: 29273006. DOI: 10.1186/s12885-017-3875-3

38 Huang J, Xiao D, Li G, Ma J, Chen P, Yuan W, Hou F, Ge J, Zhong M, Tang Y, Xia X and Chen Z: EphA2 promotes epithelial-mesenchymal transition through the $\mathrm{Wnt} / \beta$-catenin pathway in gastric cancer cells. Oncogene 33(21): 2737-2747, 2014. PMID: 23752181. DOI: 10.1038/onc.2013.238

39 Inokuchi M, Nakagawa M, Baogok N, Takagi Y, Tanioka T, Gokita K, Okuno K and Kojima K: Prognostic significance of high EphA1-4 expression levels in locally advanced gastric cancer. Anticancer Res 38(3): 1685-1693, 2018. PMID: 29491103. DOI: 10.21873 /anticanres. 12402

40 Xin L, Liu L, Liu C, Zhou LQ, Zhou Q, Yuan YW, Li SH and Zhang HT: DNA-methylation-mediated silencing of miR-7-5p promotes gastric cancer stem cell invasion via increasing Smo and Hes1. J Cell Physiol 235(3): 2643-2654, 2020. PMID: 31517391. DOI: $10.1002 /$ jcp. 29168

41 Dhanesh SB, Subashini C and James J: Hes1: the maestro in neurogenesis. Cell Mol Life Sci 73(21): 4019-4042, 2016. PMID: 27233500. DOI: 10.1007/s00018-016-2277-z

42 Akyala AI and Peppelenbosch MP: Gastric cancer and Hedgehog signaling pathway: emerging new paradigms. Genes Cancer 9(1-2): 1-10, 2018. PMID: 29725500. DOI: 10.18632/ genesandcancer.168

43 Yang Z, Lv Y, Wang L, Chen Y, Han J, Zhao S and Liu W: Inhibition of hedgehog pathway reveals the regulatory role of SMO in gastric cancer cells. Tumour Biol 39(7): 1010428317715546, 2017. PMID: 28675107. DOI: $10.1177 / 1010428317715546$

44 Tang Y, Liu X, Su B, Zhang Z, Zeng X, Lei Y, Shan J, Wu Y, Tang $\mathrm{H}$ and Su Q: microRNA-22 acts as a metastasis suppressor by targeting metadherin in gastric cancer. Molecular Medicine Reports 11(1): 454-460, 2018. DOI: 10.3892/mmr.2014.2682 
$45 \mathrm{Hu}$ G, Wei $\mathrm{Y}$ and Kang $\mathrm{Y}$ : The multifaceted role of MTDH/AEG-1 in cancer progression. Clin Cancer Res 15(18): 5615-5620, 2009. PMID: 19723648. DOI: 10.1158/10780432.CCR-09-0049

46 Dhiman G, Srivastava N, Goyal M, Rakha E, Lothion-Roy J, Mongan NP, Miftakhova RR, Khaiboullina SF, Rizvanov AA and Baranwal M: Metadherin: a therapeutic target in multiple cancers. Front Oncol 9: 349, 2019. PMID: 31131259. DOI: 10.3389/fonc.2019.00349

47 Feng D, Yu X, Tian X, Meng H, Jiang Y, Song H, Li W, Zhang $\mathrm{H}$ and Geng J: Metadherin promotes malignant phenotypes and induces beta-catenin nuclear translocation and epithelialmesenchymal transition in gastric cancer. Cancer Manag Res 11: 8911-8921, 2019. PMID: 31632151. DOI: 10.2147/ CMAR.S221422

48 Han TS, Hur K, Xu G, Choi B, Okugawa Y, Toiyama Y, Oshima H, Oshima M, Lee HJ, Kim VN, Chang AN, Goel A and Yang HK: MicroRNA-29c mediates initiation of gastric carcinogenesis by directly targeting ITGB1. Gut 64(2): 203-214, 2015. PMID: 24870620. DOI: 10.1136/gutjnl-2013-306640

49 Blandin AF, Renner G, Lehmann M, Lelong-Rebel I, Martin S and Dontenwill M: $\beta 1$ integrins as therapeutic targets to disrupt hallmarks of cancer. Front Pharmacol 6: 279, 2015. PMID: 26635609. DOI: 10.3389/fphar.2015.00279

50 Brakebusch C, Wennerberg K, Krell HW, Weidle UH, Sallmyr A, Johansson S and Fässler R: Beta1 integrin promotes but is not essential for metastasis of ras-myc transformed fibroblasts. Oncogene 18(26): 3852-3861, 1999. PMID: 10445848. DOI 10.1038/sj.onc. 1202770

51 Bloch W, Forsberg E, Lentini S, Brakebusch C, Martin K, Krell HW, Weidle UH, Addicks $\mathrm{K}$ and Fässler R: Beta 1 integrin is essential for teratoma growth and angiogenesis. J Cell Biol 139(1): 265-278, 1997. PMID: 9314545. DOI: 10.1083/ jcb.139.1.265

52 Yu B, Lv X, Su L, Li J, Yu Y, Gu Q, Yan M, Zhu Z and Liu B: MiR-148a functions as a tumor suppressor by targeting CCKBR via inactivating STAT3 and Akt in human gastric cancer. PLoS One 11(8): e0158961, 2016. PMID: 27518872. DOI 10.1371/journal.pone.0158961

53 Rai R, Chandra V, Tewari M, Kumar M and Shukla HS: Cholecystokinin and gastrin receptors targeting in gastrointestinal cancer. Surg Oncol 21(4): 281-292, 2012. PMID: 22801592. DOI: 10.1016/j.suronc.2012.06.004

54 Smith JP, Nadella S and Osborne N: Gastrin and gastric cancer. Cell Mol Gastroenterol Hepatol 4(1): 75-83, 2017. PMID 28560291. DOI: 10.1016/j.jcmgh.2017.03.004

$55 \mathrm{Xu} \mathrm{W}$, Chen GS, Shao Y, Li XL, Xu HC, Zhang H, Zhu GQ, Zhou YC, He XP and Sun WH: Gastrin acting on the cholecystokinin2 receptor induces cyclooxygenase-2 expression through JAK2/STAT3/PI3K/Akt pathway in human gastric cancer cells. Cancer Lett 332(1): 11-18, 2013. PMID: 23376640. DOI: 10.1016/j.canlet.2012.12.030

56 Tie J, Pan Y, Zhao L, Wu K, Liu J, Sun S, Guo X, Wang B, Gang Y, Zhang Y, Li Q, Qiao T, Zhao Q, Nie Y and Fan D: MiR-218 inhibits invasion and metastasis of gastric cancer by targeting the Robo1 receptor. PLoS Genet 6(3): e1000879, 2010. PMID: 20300657. DOI: 10.1371/journal.pgen.1000879

57 Bisiak $F$ and McCarthy AA: Structure and function of roundabout receptors. Subcell Biochem 93: 291-319, 2019. PMID: 31939155. DOI: 10.1007/978-3-030-28151-9_9
58 Seth P, Lin Y, Hanai J, Shivalingappa V, Duyao MP and Sukhatme VP: Magic roundabout, a tumor endothelial marker: expression and signaling. Biochem Biophys Res Commun 332(2): 533-541, 2005. PMID: 15894287. DOI: $10.1016 /$ j.bbrc .2005 .03 .250

59 Shi R, Yang Z, Liu W, Liu B, Xu Z and Zhang Z: Knockdown of Slit2 promotes growth and motility in gastric cancer cells via activation of AKT/ $\beta$-catenin. Oncol Rep 31(2): 812-818, 2014. PMID: 24297051. DOI: 10.3892/or.2013.2887

60 Wang SM, Tie J, Wang WL, Hu SJ, Yin JP, Yi XF, Tian ZH, Zhang XY, Li MB, Li ZS, Nie YZ, Wu KC and Fan DM: POU2F2-oriented network promotes human gastric cancer metastasis. Gut 65(9): 1427-1438, 2016. PMID: 26019213. DOI: 10.1136/gutjnl-2014-308932

61 Gara RK, Kumari S, Ganju A, Yallapu MM, Jaggi M and Chauhan SC: Slit/Robo pathway: a promising therapeutic target for cancer. Drug Discov Today 20(1): 156-164, 2015. PMID: 25245168. DOI: 10.1016/j.drudis.2014.09.008

62 Peng Y, Liu YM, Li LC, Wang LL and Wu XL: MicroRNA-338 inhibits growth, invasion and metastasis of gastric cancer by targeting NRP1 expression. PLoS One 9(4): e94422, 2014. PMID: 24736504. DOI: 10.1371/journal.pone.0094422

63 Niland S and Eble JA: Neuropilins in the context of tumor vasculature. Int J Mol Sci 20(3): 639, 2019. PMID: 30717262. DOI: $10.3390 /$ ijms 20030639

$64 \mathrm{Hu} \mathrm{C}$ and Jiang X: Role of NRP-1 in VEGF-VEGFR2independent tumorigenesis. Target Oncol 11(4): 501-505, 2016. PMID: 26916409. DOI: 10.1007/s11523-016-0422-0

65 Weekes CD, Beeram M, Tolcher AW, Papadopoulos KP, Gore L, Hegde P, Xin Y, Yu R, Shih LM, Xiang H, Brachmann RK and Patnaik A: A phase I study of the human monoclonal antiNRP1 antibody MNRP1685A in patients with advanced solid tumors. Invest New Drugs 32(4): 653-660, 2014. PMID: 24604265. DOI: $10.1007 / \mathrm{s} 10637-014-0071-\mathrm{Z}$

66 Cao Q, Liu F, Ji K, Liu N, He Y, Zhang W and Wang L: MicroRNA-381 inhibits the metastasis of gastric cancer by targeting TMEM16A expression. J Exp Clin Cancer Res 36(1): 29, 2017. PMID: 28193228. DOI: 10.1186/s13046-017-0499-z

67 Kunzelmann K, Tian Y, Martins JR, Faria D, Kongsuphol P, Ousingsawat J, Thevenod F, Roussa E, Rock J and Schreiber R: Anoctamins. Pflugers Arch 462(2): 195-208, 2011. PMID: 21607626. DOI: $10.1007 /$ s00424-011-0975-9

68 Katsuno Y, Lamouille S and Derynck R: TGF- $\beta$ signaling and epithelial-mesenchymal transition in cancer progression. Curr Opin Oncol 25(1): 76-84, 2013. PMID: 23197193. DOI: 10.1097/CCO.0b013e32835b6371

69 Duvvuri U, Shiwarski DJ, Xiao D, Bertrand C, Huang X, Edinger RS, Rock JR, Harfe BD, Henson BJ, Kunzelmann K, Schreiber R, Seethala RS, Egloff AM, Chen X, Lui VW, Grandis JR and Gollin SM: TMEM16A induces MAPK and contributes directly to tumorigenesis and cancer progression. Cancer Res 72(13): 3270-3281, 2012. PMID: 22564524. DOI: 10.1158/0008-5472.CAN-12-0475-T

70 Liu F, Cao QH, Lu DJ, Luo B, Lu XF, Luo RC and Wang XG: TMEM16A overexpression contributes to tumor invasion and poor prognosis of human gastric cancer through TGF- $\beta$ signaling. Oncotarget 6(13): 11585-11599, 2015. PMID: 25839162. DOI: $10.18632 /$ oncotarget.3412

71 Picollo A, Malvezzi M and Accardi A: TMEM16 proteins: unknown structure and confusing functions. J Mol Biol 427(1): 
94-105, 2015. PMID: 25451786. DOI: 10.1016/j.jmb. 2014.09.028

72 Lu Z, Luo T, Nie M, Pang T, Zhang X, Shen X, Ma L, Bi J, Wei G, Fang G and Xue X: TSPAN1 functions as an oncogene in gastric cancer and is downregulated by miR-573. FEBS Lett 589(15): 1988-1994, 2015. PMID: 26054975. DOI: 10.1016/ j.febslet.2015.05.044

73 Chen L, Li X, Wang GL, Wang Y, Zhu YY and Zhu J: Clinicopathological significance of overexpression of TSPAN1, Ki67 and CD34 in gastric carcinoma. Tumori 94(4): 531-538, 2008. PMID: 18822690.

74 Qi W, Sun L, Liu N, Zhao S, Lv J and Qiu W: Tetraspanin family identified as the central genes detected in gastric cancer using bioinformatics analysis. Mol Med Rep 18(4): 3599-3610, 2018. PMID: 30106120. DOI: 10.3892/mmr.2018.9360

75 Wang Y, Liang Y, Yang G, Lan Y, Han J, Wang J, Yin D, Song R, Zheng T, Zhang S, Pan S, Liu X, Zhu M, Liu Y, Cui Y, Meng F, Zhang B, Liang S, Guo H, Liu Y, Hassan MK and Liu L: Tetraspanin 1 promotes epithelial-to-mesenchymal transition and metastasis of cholangiocarcinoma via PI3K/AKT signaling. J Exp Clin Cancer Res 37(1): 300, 2018. PMID: 30514341. DOI: 10.1186/s13046-018-0969-y

76 Schiemann S, Schwirzke M, Brünner $\mathrm{N}$ and Weidle UH: Molecular analysis of two mammary carcinoma cell lines at the transcriptional level as a model system for progression of breast cancer. Clin Exp Metastasis 16(2): 129-139, 1998. PMID: 9514094. DOI: 10.1023/a:1021941203905

77 Gnirke AU and Weidle UH: Investigation of prevalence and regulation of expression of progression associated protein (PAP). Anticancer Res 18(6A): 4363-4369, 1998. PMID: 9891493.

78 Hemler ME: Targeting of tetraspanin proteins-potential benefits and strategies. Nat Rev Drug Discov 7(9): 747-758, 2008. PMID: 18758472 . DOI: $10.1038 / \mathrm{nrd} 2659$

79 Jiang B, Li Z, Zhang W, Wang H, Zhi X, Feng J, Chen Z, Zhu Y, Yang L, Xu H and Xu Z: miR-874 Inhibits cell proliferation, migration and invasion through targeting aquaporin-3 in gastric cancer. J Gastroenterol 49(6): 1011-1025, 2014. PMID: 23800944. DOI: $10.1007 / \mathrm{s} 00535-013-0851-9$

80 Dajani S, Saripalli A and Sharma-Walia N: Water transport proteins-aquaporins (AQPs) in cancer biology. Oncotarget 9(91): 36392-36405, 2018. PMID: 30555637. DOI: 10.18632/ oncotarget.26351

81 De Ieso ML and Yool AJ: Mechanisms of aquaporin-facilitated cancer invasion and metastasis. Front Chem 6: 135, 2018. PMID: 29922644. DOI: 10.3389/fchem.2018.00135

82 Marlar S, Jensen HH, Login FH and Nejsum LN: Aquaporin-3 in cancer. Int J Mol Sci 18(10): 2106, 2017. PMID: 28991174. DOI: $10.3390 /$ ijms 18102106

83 Moosavi MS and Elham Y: Aquaporins 1, 3 and 5 in different tumors, their expression, prognosis value and role as new therapeutic targets. Pathol Oncol Res 26(2): 615-625, 2020. PMID: 30927206. DOI: 10.1007/s12253-019-00646-9

84 Zhang JX, Xu Y, Gao Y, Chen C, Zheng ZS, Yun M, Weng HW, Xie D and Ye S: Decreased expression of miR-939 contributes to chemoresistance and metastasis of gastric cancer via dysregulation of SLC34A2 and Raf/MEK/ERK pathway. Mol Cancer 16(1): 18, 2017. PMID: 28114937. DOI: 10.1186/s12943-017-0586-y

85 Marks J: The role of SLC34A2 in intestinal phosphate absorption and phosphate homeostasis. Pflugers Arch 471(1):
165-173, 2019. PMID: 30343332. DOI: 10.1007/s00424-0182221-1

86 Duan Y, Hu L, Liu B, Yu B, Li J, Yan M, Yu Y, Li C, Su L, Zhu Z, Xiang M, Liu B and Yang Q: Tumor suppressor miR-24 restrains gastric cancer progression by downregulating RegIV. Mol Cancer 13: 127, 2014. PMID: 24886316. DOI: 10.1186/1476-4598-13-127

87 Zhang YW, Ding LS and Lai MD: Reg gene family and human diseases. World J Gastroenterol 9(12): 2635-2641, 2003. PMID: 14669303. DOI: 10.3748 /wjg.v9.i12.2635

88 Numata M and Oshima T: Significance of regenerating isletderived type IV gene expression in gastroenterological cancers. World J Gastroenterol 18(27): 3502-3510, 2012. PMID: 22826614. DOI: $10.3748 / w j g . v 18 . i 27.3502$

89 Si Y, Zhang H, Ning T, Bai M, Wang Y, Yang H, Wang X, Li J, Ying $\mathrm{G}$ and $\mathrm{Ba}$ Y: miR-26a/b inhibit tumor growth and angiogenesis by targeting the HGF-VEGF axis in gastric carcinoma. Cell Physiol Biochem 42(4): 1670-1683, 2017. PMID: 28738343. DOI: 10.1159/000479412

90 Anestis A, Zoi I and Karamouzis MV: Current advances of targeting $\mathrm{HGF} / \mathrm{c}-\mathrm{Met}$ pathway in gastric cancer. Ann Transl Med 6(12): 247, 2018. PMID: 30069449. DOI: 10.21037/atm.2018.04.42

91 Gholamin S, Fiuji H, Maftouh M, Mirhafez R, Shandiz FH and Avan A: Targeting c-MET/HGF signaling pathway in upper gastrointestinal cancers: rationale and progress. Curr Drug Targets 15(14): 1302-1311, 2014. PMID: 25382190. DOI: $10.2174 / 1389450115666141107105456$

92 Kawakami H and Okamoto I: MET-targeted therapy for gastric cancer: the importance of a biomarker-based strategy. Gastric Cancer 19(3): 687-695, 2016. PMID: 26690587. DOI: 10.1007/s 10120-015-0585-x

93 Bradley CA, Salto-Tellez M, Laurent-Puig P, Bardelli A, Rolfo C, Tabernero J, Khawaja HA, Lawler M, Johnston PG, Van Schaeybroeck S and MErCuRIC consortium: Targeting c-MET in gastrointestinal tumours: rationale, opportunities and challenges. Nat Rev Clin Oncol 14(9): 562-576, 2017. PMID: 28374784. DOI: $10.1038 /$ nrclinonc. 2017.40

94 Cheng F, Yang Z, Huang F, Yin L, Yan G and Gong G: microRNA-107 inhibits gastric cancer cell proliferation and metastasis by targeting PI3K/AKT pathway. Microb Pathog 121: 110-114, 2018. PMID: 29715534. DOI: 10.1016/j.micpath.2018.04.060

95 Khotskaya YB, Holla VR, Farago AF, Mills Shaw KR, MericBernstam F and Hong DS: Targeting TRK family proteins in cancer. Pharmacol Ther 173: 58-66, 2017. PMID: 28174090. DOI: $10.1016 /$ j.pharmthera.2017.02.006

96 Chen H, Li L, Wang S, Lei Y, Ge Q, Lv N, Zhou X and Chen C: Reduced miR-126 expression facilitates angiogenesis of gastric cancer through its regulation on VEGF-A. Oncotarget 5(23): 11873-11885, 2014. PMID: 25428912. DOI: 10.18632/oncotarget.2662

97 Ferrara N, Gerber HP and LeCouter J: The biology of VEGF and its receptors. Nat Med 9(6): 669-676, 2003. PMID: 12778165. DOI: $10.1038 / \mathrm{nm} 0603-669$

98 Carmeliet P: VEGF as a key mediator of angiogenesis in cancer. Oncology 69(Suppl 3): 4-10, 2005. PMID: 16301830. DOI: $10.1159 / 000088478$

99 Khan U and Shah MA: Ramucirumab for the treatment of gastric or gastro-esophageal junction cancer. Expert Opin Biol 
Ther 19(11): 1135-1141, 2019. PMID: 31452409. DOI: 10.1080/14712598.2019.1656715

100 Zhang W and Li Y: miR-148a downregulates the expression of transforming growth factor- $\beta 2$ and SMAD2 in gastric cancer. Int J Oncol 48(5): 1877-1885, 2016. PMID: 26983401. DOI: 10.3892/ijo.2016.3437

101 Massagué J: TGFbeta in cancer. Cell 134(2): 215-230, 2008. PMID: 18662538. DOI: 10.1016/j.cell.2008.07.001

102 Massagué J: TGF $\beta$ signalling in context. Nat Rev Mol Cell Biol 13(10): 616-630, 2012. PMID: 22992590. DOI: 10.1038/ nrm3434

103 Luo J, Chen XQ and Li P: The role of TGF- $\beta$ and its receptors in gastrointestinal cancers. Transl Oncol 12(3): 475-484, 2019. PMID: 30594036. DOI: 10.1016/j.tranon.2018.11.010

$104 \mathrm{Hu}$ WQ, Wang LW, Yuan JP, Yan SG, Li JD, Zhao HL, Peng $\mathrm{CW}$, Yang GF and Li Y: High expression of transforming growth factor beta 1 in gastric cancer confers worse outcome: results of a cohort study on 184 patients. Hepatogastroenterology 61(129): 245-250, 2014. PMID: 24895830.

105 Wang J, Li L, Jiang M and Li Y: MicroRNA-195 inhibits human gastric cancer by directly targeting basic fibroblast growth factor. Clin Transl Oncol 19(11): 1320-1328, 2017. PMID: 28500362. DOI: 10.1007/s12094-017-1668-4

106 Akl MR, Nagpal P, Ayoub NM, Tai B, Prabhu SA, Capac CM, Gliksman M, Goy A and Suh KS: Molecular and clinical significance of fibroblast growth factor 2 (FGF2/bFGF) in malignancies of solid and hematological cancers for personalized therapies. Oncotarget 7(28): 44735-44762, 2016 PMID: 27007053. DOI: 10.18632/oncotarget.8203

107 Ornitz DM and Itoh N: The Fibroblast Growth Factor signaling pathway. Wiley Interdiscip Rev Dev Biol 4(3): 215-266, 2015. PMID: 25772309. DOI: 10.1002/wdev.176

108 Zhang W, Chu YQ, Ye ZY, Zhao ZS and Tao HQ: Expression of hepatocyte growth factor and basic fibroblast growth factor as prognostic indicators in gastric cancer. Anat Rec (Hoboken) 292(8): 1114-1121, 2009. PMID: 19533745. DOI: 10.1002/ar.20934

109 Zhang J, Zhou Y, Huang T, Wu F, Pan Y, Dong Y, Wang Y, Chan AKY, Liu L, Kwan JSH, Cheung AHK, Wong CC, Lo AKF, Cheng ASL, Yu J, Lo KW, Kang W and To KF: FGF18, a prominent player in FGF signaling, promotes gastric tumorigenesis through autocrine manner and is negatively regulated by miR-590-5p. Oncogene 38(1): 33-46, 2019. PMID: 30082912. DOI: 10.1038/s41388-018-0430-x

110 Zhang J, Tang PMK, Zhou Y, Cheng ASL, Yu J, Kang W and To KF: Targeting the oncogenic FGF-FGFR axis in gastric carcinogenesis. Cells 8(6): 637, 2019. PMID: 31242658. DOI: $10.3390 /$ cells 8060637

111 Wei W, Mok SC, Oliva E, Kim SH, Mohapatra G and Birrer MJ: FGF18 as a prognostic and therapeutic biomarker in ovarian cancer. J Clin Invest 123(10): 4435-4448, 2013. PMID: 24018557. DOI: $10.1172 / J C I 70625$

112 Chae YK, Ranganath K, Hammerman PS, Vaklavas C, Mohindra N, Kalyan A, Matsangou M, Costa R, Carneiro B, Villaflor VM, Cristofanilli M and Giles FJ: Inhibition of the fibroblast growth factor receptor (FGFR) pathway: the current landscape and barriers to clinical application. Oncotarget $8(9)$ : 16052-16074, 2017. PMID: 28030802. DOI: 10.18632/ oncotarget.14109

113 Blackwell C, Sherk C, Fricko M, Ganji G, Barnette M, Hoang B, Tunstead J, Skedzielewski T, Alsaid H, Jucker BM, Minthorn
E, Kumar R and DeYoung MP: Inhibition of FGF/FGFR autocrine signaling in mesothelioma with the FGF ligand trap, FP-1039/GSK3052230. Oncotarget 7(26): 39861-39871, 2016. PMID: 27223434. DOI: 10.18632/oncotarget.9515

114 Saichaemchan S, Ariyawutyakorn W and Varella-Garcia M: Fibroblast growth factor receptors: from the oncogenic pathway to targeted therapy. Curr Mol Med 16(1): 40-62, 2016. PMID: 26695695. DOI: $10.2174 / 1566524016666151222144231$

115 Jia L, Chen J, Xie C, Shao L, Xu Z and Zhang L: microRNA$1228^{*}$ impairs the pro-angiogenic activity of gastric cancer cells by targeting macrophage migration inhibitory factor. Life Sci 180: 9-16, 2017. PMID: 28465246. DOI: 10.1016/ j.lfs.2017.04.023

116 Bloom J, Sun S and Al-Abed Y: MIF, a controversial cytokine: a review of structural features, challenges, and opportunities for drug development. Expert Opin Ther Targets 20(12): 1463-1475, 2016. PMID: 27762152. DOI: 10.1080/14728222.2016.1251582

117 Guda MR, Rashid MA, Asuthkar S, Jalasutram A, Caniglia JL, Tsung AJ and Velpula KK: Pleiotropic role of macrophage migration inhibitory factor in cancer. Am J Cancer Res 9(12): 2760-2773, 2019. PMID: 31911860.

118 Wu L, Chen J, Ding C, Wei S, Zhu Y, Yang W, Zhang X, Wei $X$ and Han D: MicroRNA-137 contributes to dampened tumorigenesis in human gastric cancer by targeting AKT2. PLoS One 10(6): e0130124, 2015. PMID: 26102366. DOI: 10.1371/journal.pone. 0130124

119 Song M, Bode AM, Dong Z and Lee MH: AKT as a therapeutic target for cancer. Cancer Res 79(6): 1019-1031, 2019. PMID: 30808672. DOI: $10.1158 / 0008-5472$.CAN-18-2738

120 Shariati M and Meric-Bernstam F: Targeting AKT for cancer therapy. Expert Opin Investig Drugs 28(11): 977-988, 2019. PMID: 31594388. DOI: 10.1080/13543784.2019.1676726

121 Zeng B, Shi W and Tan G: MiR-199a/b-3p inhibits gastric cancer cell proliferation via down-regulating PAK4/MEK/ERK signaling pathway. BMC Cancer 18(1): 34, 2018. PMID: 29304764. DOI: 10.1186/s12885-017-3949-2

$122 \mathrm{Li} \mathrm{X}$, Li J and Li F: P21 activated kinase 4 binds translation elongation factor eEF1A1 to promote gastric cancer cell migration and invasion. Oncol Rep 37(5): 2857-2864, 2017. PMID: 28393218. DOI: 10.3892/or.2017.5543

123 Won SY, Park JJ, Shin EY and Kim EG: PAK4 signaling in health and disease: defining the PAK4-CREB axis. Exp Mol Med 51(2): 1-9, 2019. PMID: 30755582. DOI: 10.1038/s12276018-0204-0

124 Kobayashi K, Inokuchi M, Takagi Y, Otsuki S, Fujimori Y, Sato Y, Yanaka Y, Higuchi K, Aburatani T, Tomii C, Uetake H, Kojima $\mathrm{K}$ and Kawano T: Prognostic significance of PAK4 expression in gastric cancer. J Clin Pathol 69(7): 580-585, 2016. PMID: 26614788. DOI: 10.1136/jclinpath-2015-203330

125 Li D, Zhang Y, Li Z, Wang X, Qu X and Liu Y: Activated Pak4 expression correlates with poor prognosis in human gastric cancer patients. Tumour Biol 36(12): 9431-9436, 2015. PMID: 26124003. DOI: $10.1007 / \mathrm{s} 13277-015-3368-4$

126 Gao P, Wang S, Jing F, Zhan J and Wang Y: microRNA-203 suppresses invasion of gastric cancer cells by targeting ERK1/2/Slug/ E-cadherin signaling. Cancer Biomark 19(1): 1120, 2017. PMID: 28269747. DOI: 10.3233/CBM-160167

127 Roskoski R Jr: Targeting ERK1/2 protein-serine/threonine kinases in human cancers. Pharmacol Res 142: 151-168, 2019. PMID: 30794926. DOI: 10.1016/j.phrs.2019.01.039 
128 Pathania S and Rawal RK: An update on chemical classes targeting ERK1/2 for the management of cancer. Future Med Chem 12(7): 593-611, 2020. PMID: 32191540. DOI: 10.4155/fmc-2019-0339

129 Fang Z, Yin S, Sun R, Zhang S, Fu M, Wu Y, Zhang T, Khaliq J and Li Y: miR-140-5p suppresses the proliferation, migration and invasion of gastric cancer by regulating YES1. Mol Cancer 16(1): 139, 2017. PMID: 28818100. DOI: 10.1186/s12943-017-0708-6

130 Rai K: Personalized Cancer Therapy: YES1 is the new kid on the block. Cancer Res 79(22): 5702-5703, 2019. PMID: 31772072. DOI: 10.1158/0008-5472.CAN-19-2995

131 Jung J, Lee MK, Jin Y, Fu SB, Rosales JL and Lee KY: Clues for c-Yes involvement in the cell cycle and cytokinesis. Cell Cycle 10(9): 1502-1503, 2011. PMID: 21566460. DOI: 10.4161/cc.10.9.15495

132 Hamanaka N, Nakanishi Y, Mizuno T, Horiguchi-Takei K, Akiyama N, Tanimura H, Hasegawa M, Satoh Y, Tachibana Y, Fujii T, Sakata K, Ogasawara K, Ebiike H, Koyano H, Sato H, Ishii $\mathrm{N}$ and Mio T: YES1 is a targetable oncogene in cancers harboring YES1 gene amplification. Cancer Res 79(22): 57345745, 2019. PMID: 31391186. DOI: 10.1158/0008-5472.CAN$18-3376$

133 Ding L, Xu Y, Zhang W, Deng Y, Si M, Du Y, Yao H, Liu X, Ke Y, Si J and Zhou T: MiR-375 frequently downregulated in gastric cancer inhibits cell proliferation by targeting JAK2. Cell Res 20(7): 784-793, 2010. PMID: 20548334. DOI: $10.1038 / \mathrm{cr} .2010 .79$

134 Levine RL, Pardanani A, Tefferi A and Gilliland DG: Role of JAK2 in the pathogenesis and therapy of myeloproliferative disorders. Nat Rev Cancer 7(9): 673-683, 2007. PMID: 17721432. DOI: $10.1038 / \mathrm{nrc} 2210$

135 Kumar C, Purandare AV, Lee FY and Lorenzi MV: Kinase drug discovery approaches in chronic myeloproliferative disorders. Oncogene 28(24): 2305-2313, 2009. PMID: 19421140. DOI: 10.1038/onc.2009.107

136 Bose $\mathrm{P}$ and Verstovsek S: JAK2 inhibitors for myeloproliferative neoplasms: what is next? Blood 130(2): 115125, 2017. PMID: 28500170. DOI: 10.1182/blood-2017-04742288

137 Wang M, Chen L, Chen Y, Wei R, Guo Q, Zhu S, Guo S, Zhu $\mathrm{S}$, Zhang $\mathrm{S}$ and Min L: Intracellular matrix Gla protein promotes tumor progression by activating JAK2/STAT5 signaling in gastric cancer. Mol Oncol 14(5): 1045-1058, 2020. PMID: 32086862. DOI: 10.1002/1878-0261.12652

138 Wang J, Wen T, Li Z, Che X, Gong L, Yang X, Zhang J, Tang $\mathrm{H}, \mathrm{He} \mathrm{L}, \mathrm{Qu}$ X and Liu Y: MicroRNA-1224 inhibits tumor metastasis in intestinal-type gastric cancer by directly targeting FAK. Front Oncol 9: 222, 2019. PMID: 31019895. DOI: 10.3389/fonc.2019.00222

139 Lv PC, Jiang AQ, Zhang WM and Zhu HL: FAK inhibitors in Cancer, a patent review. Expert Opin Ther Pat 28(2): 139-145, 2018. PMID: 29210300. DOI: 10.1080/13543776. 2018.1414183

140 Mousson A, Sick E, Carl P, Dujardin D, De Mey J and Rondé P: Targeting focal adhesion kinase using inhibitors of proteinprotein interactions. Cancers (Basel) 10(9): 278, 2018. PMID: 30134553. DOI: 10.3390/cancers 10090278

141 Tai YL, Chen LC and Shen TL: Emerging roles of focal adhesion kinase in cancer. Biomed Res Int 2015: 690690, 2015. PMID: 25918719. DOI: 10.1155/2015/690690
142 Lee BY, Timpson P, Horvath LG and Daly RJ: FAK signaling in human cancer as a target for therapeutics. Pharmacol Ther 146: 132-149, 2015. PMID: 25316657. DOI: 10.1016/ j.pharmthera.2014.10.001

143 Zhang LL, Liu J, Lei S, Zhang J, Zhou W and Yu HG: PTEN inhibits the invasion and metastasis of gastric cancer via downregulation of FAK expression. Cell Signal 26(5): 1011-1020, 2014. PMID: 24486402. DOI: 10.1016/j.cellsig.2014.01.025

144 Li J, Meng Q, Sun Y and Qing H: Inhibition of focal adhesion kinase induces apoptosis in human gastric carcinoma cells (SGC-7901). Mol Biol Rep 40(1): 401-406, 2013. PMID: 23065253. DOI: 10.1007/s11033-012-2074-1

$145 \mathrm{Xu}$ J, Zhang Z, Chen Q, Yang L and Yin J: miR-146b regulates cell proliferation and apoptosis in gastric cancer by targeting PTP1B. Dig Dis Sci 65(2): 457-463, 2020. PMID: 31441000. DOI: $10.1007 / \mathrm{s} 10620-019-05771-8$

146 Sun F, Yu M, Yu J, Liu Z, Zhou X, Liu Y, Ge X, Gao H, Li M, Jiang X, Liu S, Chen X and Guan W: miR-338-3p functions as a tumor suppressor in gastric cancer by targeting PTP1B. Cell Death Dis 9(5): 522, 2018. PMID: 29743567. DOI: 10.1038/s41419-018-0611-0

147 Lessard L, Stuible M and Tremblay ML: The two faces of PTP1B in cancer. Biochim Biophys Acta 1804(3): 613-619, 2010. PMID: 19782770. DOI: 10.1016/j.bbapap.2009.09.018

148 Verma M, Gupta SJ, Chaudhary A and Garg VK: Protein tyrosine phosphatase 1B inhibitors as antidiabetic agents - A brief review. Bioorg Chem 70: 267-283, 2017. PMID: 28043717. DOI: $10.1016 /$ j.bioorg.2016.12.004

149 Zhang D, Xiao YF, Zhang JW, Xie R, Hu CJ, Tang B, Wang SM, Wu YY, Hao NB and Yang SM: miR-1182 attenuates gastric cancer proliferation and metastasis by targeting the open reading frame of hTERT. Cancer Lett 360(2): 151-159, 2015. PMID: 25662441. DOI: 10.1016/j.canlet.2015.01.044

150 Chen L, Lü MH, Zhang D, Hao NB, Fan YH, Wu YY, Wang SM, Xie R, Fang DC, Zhang H, Hu CJ and Yang SM: miR1207-5p and miR-1266 suppress gastric cancer growth and invasion by targeting telomerase reverse transcriptase. Cell Death Dis 5: e1034, 2014. PMID: 24481448. DOI: 10.1038/cddis.2013.553

151 Arndt GM and MacKenzie KL: New prospects for targeting telomerase beyond the telomere. Nat Rev Cancer 16(8): 508524, 2016. PMID: 27339602. DOI: 10.1038/nrc.2016.55

$152 \mathrm{Wu}$ L, Fidan K, Um JY and Ahn KS: Telomerase: Key regulator of inflammation and cancer. Pharmacol Res 155: 104726, 2020. PMID: 32109579. DOI: 10.1016/j.phrs.2020.104726

153 Jafri MA, Ansari SA, Alqahtani MH and Shay JW: Roles of telomeres and telomerase in cancer, and advances in telomerase-targeted therapies. Genome Med 8(1): 69, 2016. PMID: 27323951. DOI: 10.1186/s13073-016-0324-x

154 Harley CB: Telomerase and cancer therapeutics. Nat Rev Cancer 8(3): 167-179, 2008. PMID: 18256617. DOI: $10.1038 / \mathrm{nrc} 2275$

155 Lü MH, Deng JQ, Cao YL, Fang DC, Zhang Y and Yang SM: Prognostic role of telomerase activity in gastric adenocarcinoma: A meta-analysis. Exp Ther Med 3(4): 728734, 2012. PMID: 22969960. DOI: 10.3892/etm.2012.471

156 Xia J, Wu Z, Yu C, He W, Zheng H, He Y, Jian W, Chen L, Zhang L and Li W: miR-124 inhibits cell proliferation in gastric cancer through down-regulation of SPHK1. J Pathol 227(4): 470-480, 2012. PMID: 22450659. DOI: 10.1002/path.4030 
157 Wang Z, Qu H, Gong W and Liu A: Up-regulation and tumorpromoting role of SPHK1 were attenuated by miR-330-3p in gastric cancer. IUBMB Life 70(11): 1164-1176, 2018. PMID: 30281914. DOI: 10.1002/iub.1934

158 Sukocheva OA, Furuya $\mathrm{H}, \mathrm{Ng}$ ML, Friedemann $\mathrm{M}$, Menschikowski M, Tarasov VV, Chubarev VN, Klochkov SG, Neganova ME, Mangoni AA, Aliev G and Bishayee A: Sphingosine kinase and sphingosine-1-phosphate receptor signaling pathway in inflammatory gastrointestinal disease and cancers: A novel therapeutic target. Pharmacol Ther 207: 107464, 2020. PMID: 31863815. DOI: 10.1016/j.pharmthera. 2019.107464

159 Pyne NJ and Pyne S: Sphingosine 1-phosphate and cancer. Nat Rev Cancer 10(7): 489-503, 2010. PMID: 20555359. DOI: $10.1038 / \mathrm{nrc} 2875$

160 Maceyka M, Payne SG, Milstien S and Spiegel S: Sphingosine kinase, sphingosine-1-phosphate, and apoptosis. Biochim Biophys Acta 1585(2-3): 193-201, 2002. PMID: 12531554 DOI: 10.1016/s1388-1981(02)00341-4

161 Cheng Y, Li Y, Liu D, Zhang R and Zhang J: miR-137 effects on gastric carcinogenesis are mediated by targeting Cox-2activated PI3K/AKT signaling pathway. FEBS Lett 588(17): 3274-3281, 2014. PMID: 25064845. DOI: 10.1016 j.febslet.2014.07.012

162 Misra S and Sharma K: COX-2 signaling and cancer: new players in old arena. Curr Drug Targets 15(3): 347-359, 2014 PMID: 24467618. DOI: 10.2174/1389450115666140127102915

163 Echizen K, Hirose O, Maeda Y and Oshima M: Inflammation in gastric cancer: Interplay of the COX-2/prostaglandin E2 and Toll-like receptor/MyD88 pathways. Cancer Sci 107(4): 391397, 2016. PMID: 27079437. DOI: 10.1111/cas.12901

164 Takei Y, Takigahira M, Mihara K, Tarumi Y and Yanagihara K: The metastasis-associated microRNA miR-516a-3p is a novel therapeutic target for inhibiting peritoneal dissemination of human scirrhous gastric cancer. Cancer Res 71(4): 1442-1453, 2011. PMID: 21169410. DOI: 10.1158/0008-5472.CAN-10-2530

165 Takemura S, Yashiro M, Sunami T, Tendo M and Hirakawa K: Novel models for human scirrhous gastric carcinoma in vivo. Cancer Sci 95(11): 893-900, 2004. PMID: 15546507. DOI: 10.1111/j.1349-7006.2004.tb02199.x

166 Morimoto-Tomita M, Uchimura K, Werb Z, Hemmerich S and Rosen SD: Cloning and characterization of two extracellular heparin-degrading endosulfatases in mice and humans. J Biol Chem 277(51): 49175-49185, 2002. PMID: 12368295. DOI: 10.1074/jbc.M205131200

167 Ai X, Do AT, Lozynska O, Kusche-Gullberg M, Lindahl U and Emerson CP Jr: QSulf1 remodels the 6-O sulfation states of cell surface heparan sulfate proteoglycans to promote Wnt signaling. J Cell Biol 162(2): 341-351, 2003. PMID: 12860968. DOI: $10.1083 /$ jcb.200212083

168 Bafico A, Liu G, Goldin L, Harris V and Aaronson SA: An autocrine mechanism for constitutive Wnt pathway activation in human cancer cells. Cancer Cell 6(5): 497-506, 2004. PMID: 15542433. DOI: $10.1016 /$ j.ccr.2004.09.032

169 Nawroth R, van Zante A, Cervantes S, McManus M, Hebrok M and Rosen SD: Extracellular sulfatases, elements of the Wnt signaling pathway, positively regulate growth and tumorigenicity of human pancreatic cancer cells. PLoS One 2(4): e392, 2007. PMID: 17460759. DOI: 10.1371/journal. pone. 0000392
170 Wu N, Han Y, Liu H, Jiang M, Chu Y, Cao J, Lin J, Liu Y, Xu $\mathrm{B}$ and Xie X: miR-5590-3p inhibited tumor growth in gastric cancer by targeting DDX5/AKT/m-TOR pathway. Biochem Biophys Res Commun 503(3): 1491-1497, 2018. PMID: 30029874. DOI: 10.1016/j.bbrc.2018.07.068

171 Xing Z, Ma WK and Tran EJ: The DDX5/Dbp2 subfamily of DEAD-box RNA helicases. Wiley Interdiscip Rev RNA 10(2): e1519, 2019. PMID: 30506978. DOI: 10.1002/wrna.1519

172 Nyamao RM, Wu J, Yu L, Xiao X and Zhang FM: Roles of DDX5 in the tumorigenesis, proliferation, differentiation, metastasis and pathway regulation of human malignancies. Biochim Biophys Acta Rev Cancer 1871(1): 85-98, 2019. PMID: 30419318. DOI: 10.1016/j.bbcan.2018.11.003

$173 \mathrm{Wu}$ G, Xing Z, Tran EJ and Yang D: DDX5 helicase resolves G-quadruplex and is involved in $M Y C$ gene transcriptional activation. Proc Natl Acad Sci USA 116(41): 20453-20461, 2019. PMID: 31548374. DOI: 10.1073/pnas.1909047116

174 Orellana EA and Kasinski AL: MicroRNAs in cancer: A historical perspective on the path from discovery to therapy. Cancers (Basel) 7(3): 1388-1405, 2015. PMID: 26226002. DOI: $10.3390 /$ cancers 7030842

175 Taylor MA and Schiemann WP: Therapeutic opportunities for targeting microRNAs in cancer. Mol Cell Ther 2(30): 1-13, 2014. PMID: 25717380. DOI: 10.1186/2052-8426-2-30

176 Gambari R, Brognara E, Spandidos DA and Fabbri E: Targeting oncomiRNAs and mimicking tumor suppressor miRNAs: New trends in the development of miRNA therapeutic strategies in oncology (Review). Int J Oncol 49(1): 5-32, 2016. PMID: 27175518. DOI: $10.3892 / \mathrm{ijo} .2016 .3503$

177 Michelfelder S and Trepel M: Adeno-associated viral vectors and their redirection to cell-type specific receptors. Adv Genet 67: 29-60, 2009. PMID: 19914449. DOI: 10.1016/S00652660(09)67002-4

178 Garzon R, Marcucci G and Croce CM: Targeting microRNAs in cancer: rationale, strategies and challenges. Nat Rev Drug Discov 9(10): 775-789, 2010. PMID: 20885409. DOI: $10.1038 / \mathrm{nrd} 3179$

179 Esquela-Kerscher A, Trang P, Wiggins JF, Patrawala L, Cheng A, Ford L, Weidhaas JB, Brown D, Bader AG and Slack FJ: The let-7 microRNA reduces tumor growth in mouse models of lung cancer. Cell Cycle 7(6): 759-764, 2008. PMID: 18344688. DOI: $10.4161 /$ cc.7.6.5834

$180 \mathrm{Wu}$ Y, Crawford M, Mao Y, Lee RJ, Davis IC, Elton TS, Lee LJ and Nana-Sinkam SP: Therapeutic Delivery of microRNA$29 \mathrm{~b}$ by cationic lipoplexes for lung cancer. Mol Ther Nucleic Acids 2: e84, 2013. PMID: 23591808. DOI: 10.1038/ mtna.2013.14

$181 \mathrm{Wu}$ X, Liu T, Fang O, Dong W, Zhang F, Leach L, Hu X and Luo Z: MicroRNA-708-5p acts as a therapeutic agent against metastatic lung cancer. Oncotarget 7(3): 2417-2432, 2016. PMID: 26678031. DOI: 10.18632/oncotarget.6594

182 Zhang L, Liao Y and Tang L: MicroRNA-34 family: a potential tumor suppressor and therapeutic candidate in cancer. J Exp Clin Cancer Res 38(1): 53, 2019. PMID: 30717802. DOI: 10.1186/s13046-019-1059-5

183 Jones D: Setbacks shadow microRNA therapies in the clinic. Nat Biotechnol 36(10): 909-910, 2018. PMID: 30307922. DOI: 10.1038/nbt1018-909

184 van Zandwijk N, Pavlakis N, Kao SC, Linton A, Boyer MJ, Clarke S, Huynh Y, Chrzanowska A, Fulham MJ, Bailey DL, 
Cooper WA, Kritharides L, Ridley L, Pattison ST, MacDiarmid J, Brahmbhatt $\mathrm{H}$ and Reid G: Safety and activity of microRNAloaded minicells in patients with recurrent malignant pleural mesothelioma: a first-in-man, phase 1, open-label, doseescalation study. Lancet Oncol 18(10): 1386-1396, 2017. PMID: 28870611. DOI: 10.1016/S1470-2045(17)30621-6

185 Reid G, Kao SC, Pavlakis N, Brahmbhatt H, MacDiarmid J, Clarke S, Boyer M and van Zandwijk N: Clinical development of TargomiRs, a miRNA mimic-based treatment for patients with recurrent thoracic cancer. Epigenomics 8(8): 1079-1085, 2016. PMID: 27185582. DOI: $10.2217 /$ epi-2016-0035

186 MacLeod AR and Crooke ST: RNA therapeutics in oncology: advances, challenges, and future directions. J Clin Pharmacol 57(Suppl 10): S43-S59, 2017. PMID: 28921648. DOI: $10.1002 /$ jcph. 957

187 Garofalo M, Leva GD and Croce CM: MicroRNAs as anticancer therapy. Curr Pharm Des 20(33): 5328-5335, 2014. PMID: 24479801. DOI: 10.2174/1381612820666140128211346

188 Malek A, Merkel O, Fink L, Czubayko F, Kissel T and Aigner A: In vivo pharmacokinetics, tissue distribution and underlying mechanisms of various PEI(-PEG)/siRNA complexes. Toxicol Appl Pharmacol 236(1): 97-108, 2009. PMID: 19371615. DOI: 10.1016/j.taap.2009.01.014
189 Wang AZ, Langer R and Farokhzad OC: Nanoparticle delivery of cancer drugs. Annu Rev Med 63: 185-198, 2012. PMID: 21888516. DOI: 10.1146/annurev-med-040210-162544

190 Rozema DB, Lewis DL, Wakefield DH, Wong SC, Klein JJ, Roesch PL, Bertin SL, Reppen TW, Chu Q, Blokhin AV, Hagstrom JE and Wolff JA: Dynamic PolyConjugates for targeted in vivo delivery of siRNA to hepatocytes. Proc Natl Acad Sci USA 104(32): 12982-12987, 2007. PMID: 17652171. DOI: $10.1073 /$ pnas.0703778104

191 Copolovici DM, Langel K, Eriste E and Langel Ü: Cellpenetrating peptides: design, synthesis, and applications. ACS Nano 8(3): 1972-1994, 2014. PMID: 24559246. DOI: $10.1021 / \mathrm{nn} 4057269$

192 Thorén PE, Persson D, Isakson P, Goksör M, Onfelt A and Nordén B: Uptake of analogs of penetratin, Tat(48-60) and oligoarginine in live cells. Biochem Biophys Res Commun 307(1): 100-107, 2003. PMID: 12849987. DOI: 10.1016/s0006$291 x(03) 01135-5$

Received March 25, 2021

Revised April 30, 2021

Accepted May 5, 2021 